\title{
Diagnostic Spirometry in Primary Care
}

\section{Proposed standards for general practice compliant with American Thoracic Society and European Respiratory Society recommendations}

\section{A General Practice Airways Group (GPIAG)' document, in association with the Association for Respiratory Technology \& Physiology (ARTP) ${ }^{2}$ and Education for Health ${ }^{3}$}

${ }^{1}$ www.gpiag.org ${ }^{2}$ www.artp.org ${ }^{3}$ www.educationforhealth.org.uk

\section{*Mark L Levya, Philip H Quanjer ${ }^{\mathrm{b}}$, Rachel Booker ${ }^{\#}$, Brendan G Cooper ${ }^{\mathrm{d}}{ }^{\dagger}$, Stephen Holmes $^{\mathrm{e}^{\ddagger}}$, Iain R Small ${ }^{\ddagger}$}

\footnotetext{
a Senior Clinical Research Fellow, Allergy \& Respiratory Research Group, Division of Community Health Sciences:GP section, University of Edinburgh, Scotland, UK; Editor-in-Chief Primary Care Respiratory Journal

b Professor Emeritus of Physiology, Department of Pulmonary Diseases and Sophia Children's Hospital, Erasmus Medical Centre, Erasmus University, Rotterdam, The Netherlands

Independent specialist respiratory nurse and freelance medical writer; "For and on behalf of: Education for Health, The Athenaeum, 10 Church St, Warwick, UK

d Consultant Clinical Scientist; ${ }^{\dagger}$ For and on behalf of: ARTP, Suite 4, Sovereign House, Gate Lane, Boldmere, Sutton Coldfield, UK

e General Practitioner, Cannards Grave Road, Shepton Mallet, Somerset, UK; Associate Dean (GP Medical Education) Severn Deanery, Bristol, UK; GPIAG Education Lead; ₹For and on behalf of: GPIAG, Smithy House, Waterbeck, Lockerbie, Scotland, UK

f General Practitioner, Peterhead Health Centre, Links Terrace, Peterhead, Aberdeenshire, Scotland, UK; Honorary Lecturer, Centre for Academic Primary Care, University of Aberdeen, Scotland, UK; Chair of the GPIAG Executive Committee; ${ }^{\ddagger}$ For and on behalf of: GPIAG
}

Received after pre-submission external peer review and approval by all associated organisations 12th July 2009; accepted 19th July 2009; online 14th August 2009

\begin{abstract}
Primary care spirometry services can be provided by trained primary care staff, peripatetic specialist services, or through referral to hospital-based or laboratory spirometry. The first of these options is the focus of this Standards Document. It aims to provide detailed information for clinicians, managers and healthcare commissioners on the key areas of quality required for diagnostic spirometry in primary care - including training requirements and quality assurance. These proposals and recommendations are designed to raise the standard of spirometry and respiratory diagnosis in primary care and to provide the impetus for debate, improvement and maintenance of quality for diagnostic (rather than screening) spirometry performed in primary care. This document should therefore challenge current performance and should constitute an aspirational guide for delivery of this service.

(C) 2009 General Practice Airways Group. All rights reserved.

ML Levy et al. Prim Care Resp J 2009; 18(3): 130-147

doi:10.4104/pcrj.2009.00054
\end{abstract}

Keywords diagnostic spirometry, spirometry, COPD, diagnosis, guideline, standards, primary care, general practice

The full version of this paper, with online Appendices,

is available online at www.thepcrj.org.

See linked editorial by Jenkins on pg 128

\section{Introduction}

Health care should have quality at its heart, ${ }^{1}$ and should also satisfy patients' desire for care closer to home.2 Improved recognition and care of patients with chronic obstructive pulmonary disease (COPD) is underpinned by a need for high quality, reliable, diagnostic spirometry. ${ }^{3-5}$ Spirometry is recommended for the diagnosis and management of asthma and COPD in national and international guidelines, and specialist respiratory groups such as the American Thoracic and European Respiratory Societies (ATS/ERS) have published guidelines on

* Corresponding author: Dr Mark L Levy, Clo GPIAG, Smithy House, Waterbeck, Lockerbie, DG11 3EY, UK.

Tel: +44 (0)1461 600639 Fax: +44 (0)1461 207819 E-mail: marklevy@animalswild.com 
standards of spirometry. ${ }^{6}$ There are also specific guidelines ${ }^{7}$ for diagnosis of the numerous respiratory diseases presenting in primary care ('general' or 'family' practice). ${ }^{7-10}$ However, there are no overarching guidelines on current standards required for performing spirometry in the primary care setting.

Increased availability of spirometry in primary care (also termed 'office spirometry') is welcome since it provides rapid access to diagnosis and monitoring close to the patient's home. A recent UK audit of 9716 cases of people admitted to hospital with an exacerbation of COPD found a spirometry record within the last five years in 55\% of their hospital records, and in $74 \%$ of their primary care records. ${ }^{11}$ However, poorly performed tests and misinterpretation of the results can lead to misdiagnosis (or missed diagnosis) and inappropriate management, potentially putting patients at risk. Spirometry is effort-dependent, and the role of the person administering the test as 'coach' to the patient cannot be overestimated. Training and regular practice is vital. Likewise, the results of spirometry testing need to be properly interpreted in the light of the clinical history and presentation - ideally at the time of testing.

There is marked variability and inconsistency in the use of spirometry to diagnose COPD; ${ }^{12,13}$ this is related to the age of patients, ${ }^{13}$ the speciality of the clinician (primary or secondary care), ${ }^{13,14}$ and the severity of the disease. ${ }^{15}$ Variations in the presentation of results from different spirometers do not facilitate uniform interpretation. ${ }^{16}$ Where quality outcome initiatives for primary care are in place (e.g. the Quality Outcomes Framework (QOF) in the UK) there is little emphasis on the quality of spirometry performance and its interpretation. ${ }^{17}$ These factors all contribute to an ongoing national ${ }^{12,18}$ and international ${ }^{19-25}$ debate about the delivery of spirometry in the primary care setting.

Diagnosis of any disease requires a complex series of decisions based on clinical history, examination and further investigations, where appropriate. Accurate spirometry is an essential part of clinical practice in primary care differential diagnosis and management, ${ }^{7}$ including monitoring of COPD and asthma. ${ }^{23,26}$ It is therefore essential that those performing spirometry are trained and able to demonstrate their competence to:

- do the tests,

- identify errors, and

- interpret the results at the point of contact

Primary care spirometry services can be provided by trained primary care staff, peripatetic specialist services, or through referral to hospital-based or laboratory spirometry. The first of these options is the focus of this paper. This guidance aims to provide detailed information for clinicians, managers and healthcare commissioners on the key areas of quality expected for diagnostic spirometry in primary care - including training requirements and quality assurance. There will always be a gap between standards and practice, and therefore it is not the authors' intention that all these standards and recommendations be met immediately, or that spirometry should not be performed in primary care. Neither is it the intention of the authors to denigrate the quality of spirometry currently provided in primary care; whilst there are variations in delivery of this service, there are certainly examples of high quality performance.

Therefore, this Standards Document provides background information and specific recommendations on the key quality areas for performing spirometry in primary care. The authorship includes international experts on spirometry and representatives from the General Practice Airways Group (GPIAG), the Association for Respiratory Technology \& Physiology (ARTP), and Education For Health (EFH). Comments from the British Thoracic Society (BTS) have been incorporated into the final document. The document is intended to provide the impetus for debate, improvement and maintenance of quality of diagnostic (rather than screening) spirometry in primary care. It should therefore challenge current spirometry performance - in order to raise standards - and act as an aspirational guide for delivery of this service.

\section{Background literature: quality of spirometry performed in primary care}

A literature search (keywords: 'spirometry'; 'quality'; and 'general practice or primary care or family practice') was undertaken, utilising the scopus database (www.scopus.com) to identify papers that addressed three issues related to spirometry in primary care:

- the training received by primary care practitioners and the effect of this in practice

- the quality of primary care spirometry

- and whether any routine quality assurance is performed in this setting.

A recent survey by The British Lung Foundation (BLF) reported perceived difficulties with the accurate diagnosis of COPD and asthma; most of the 750 UK general practitioners (GPs) surveyed reported difficulty differentiating between asthma and COPD, as did their specialist colleagues who were surveyed. ${ }^{27}$ Over $75 \%$ of these GPs owned or rented spirometers and in most cases spirometry tests in their practices are performed by nurses or health care assistants. 
Whilst the survey did not elicit the level or quality of training, or the standard of proficiency attained by staff doing spirometry, less than a quarter of the GPs stated that they were formally trained to carry out spirometry testing themselves - unsurprising in view of the above - and more than a quarter had no training to interpret spirometry tests. Another recent UK survey found that only $20 \%$ of primary care nurses who always used spirometry to diagnose COPD had undertaken formal accredited training. ${ }^{28}$

Training and effectiveness of spirometry in general practice

'Training' relates to the technical skills of the person conducting the test and also to the level to which patients are 'trained' or coached in performing the inspiratory and expiratory manoeuvres. In 1999 Eaton et al. studied the quality of spirometry in 30 randomly selected primary care practices. ${ }^{19}$ While significantly more spirometry tracings were of acceptable quality during the 16-week study (according to ATS Standards at the time), only $33.1 \%$ and $12.5 \%$ of patient tests, in groups with and without training, respectively, achieved the required minimum of two acceptable blows. Other studies at that time showed unacceptable variance between tests performed in primary care and those performed in pulmonary function laboratories. ${ }^{29,30}$ However, more recent studies have demonstrated that, with adequate and appropriate training, primary care practitioners are able to obtain high quality tests, ${ }^{21,31}$ to the extent that trained assistants performed better than trained technicians. ${ }^{21}$

Quality of primary care spirometry

From the primary care studies evaluated, the quality of spirometry performed by untrained personnel (GPs and nurses) varies. A number of primary care studies demonstrate that spirometry does not always meet good quality standards, 29,30,32 whereas others achieve specialist standards. ${ }^{21,31}$ In a comparative study, trained nurses performed better than 'usual care' GPs, although ATS spirometry standards for acceptability and reproducibility ${ }^{6}$ were met in only $76 \%$ and $44 \%$ of cases, respectively. ${ }^{33}$ The technical adequacy and accuracy of interpretation of primary care spirometry varies from unacceptable in one study ${ }^{18}$ to technically adequate in another (71\% of 368 tests performed in 12 practices ${ }^{26}$ ). However, most would argue that a level of $71 \%$ technically adequate tests falls short of an acceptable diagnostic standard.

Tuomisto et al. retrospectively assessed the quality of spirometry tracings enclosed with referral letters from Finnish GPs. ${ }^{34}$ Whilst this paper does not provide information on the level of training acquired by those doing spirometry, the authors concluded that the majority of spirometry tracings were of a high standard. Conversely, den Otter et al demonstrated that primary care spirometry does not always meet good quality standards. ${ }^{32}$

\section{Quality assurance in primary care}

No formal studies of routine assessment or quality assurance of primary care practices providing spirometry could be found in the literature. White et al. studied the level of agreement between GPs and specialists in the assessment of quality and interpretation of spirometry. ${ }^{18}$ In 312 spirometry test results from six general practices there was significant disagreement in the interpretation of the quality of the tracings, the diagnosis, and the severity of airflow obstruction. In another study, ${ }^{35}$ $28.6 \%$ of incorrect test manoeuvres were not recognised by GPs, and only $66 \%$ of their interpretations agreed with that of an expert panel. Therefore quality assurance of spirometry performed in primary care is highly desirable.

More data on the quality of training and competence in performing and interpreting spirometry is needed. However, it appears from the available data that the proportion of unacceptable tests performed in primary care is likely to be too high.

Recommendation: Individuals conducting spirometry should be trained and competent (accredited) in performing (and ideally, interpreting) the tests.

Recommendation: There is a need for systems for assessing the quality of spirometry tests, either by direct observation by trained individuals or by building in practical guidance in the form of immediate, software-driven feedback during the test procedure.

\section{Spirometry equipment, provision of service, and quality assurance}

Despite comparisons of spirometers using test rigs ${ }^{36}$ there are few clinical comparisons of the performance of different spirometers. ${ }^{37,38}$ However, differences in forced expiratory volume in one second ( $\left.\mathrm{FEV}_{1}\right)$ and forced vital capacity (FVC) recordings between different types of office spirometers have been reported. Therefore, wherever possible sequential testing should be done using the same spirometer. ${ }^{16,39}$

\section{Types of spirometer}

\section{Flow vs. Volume}

Currently most spirometers are flow-measuring devices. They are relatively low cost, and are small, more portable, and more widely available than volume-measuring devices.

Types of flow-measuring devices are:

(i) Turbine/rotating vane,

(ii) Pneumotachograph (Lilly or Fleisch type), or

(iii) Ultrasonic designs.

All three types have their merits and drawbacks and each practice should seek advice from independent experts (e.g. local lung function technologists, local practice nurse expert or respiratory nurse specialist) about which device will best suit their requirements. 
Hand held vs. bench top or personal computer/ electronic patient record-based spirometers

Stand alone, hand-held devices should be discouraged in favour of devices that allow data download and incorporation into medical records, and/or enable hard copy printouts of the results. For a practice-based service, bench top devices can be utilised at a 'spirometry station' where calibration, printing and patient safety can be upheld. Where data are stored electronically, this must be password protected.

\section{Choosing a spirometer}

The spirometer needs to be reliable and accurate. In particular, when switched on and left alone, the flow and volume output of the spirometer should be stable. The capital and running costs (consumables) of a spirometer need to be considered. Other desirable attributes include portability, robustness, ease of use, ability to upload data to a computerised medical record, and a real time graphical display which provides immediate patient and operator feedback on the acceptability of the patient's effort. The nature of the report format, including transferability to primary care computer systems, also needs to be considered. Reporting facilities need to be in line with international standards (see Table 1). Since many individual countries provide recommendations or 'buyers guides' for equipment, we have not referenced these here; the information can be obtained by searching the internet on 'Buyers Guide for Spirometers' by country.

In addition to equipment considerations, general practices will also need to think about:

- How the spirometer will be used (what categories of patients, referral processes).

- Who will be conducting and interpreting the tests (with consideration of training needs); ideally the same person should do both tasks.

- How many tests will be undertaken and whether this will be sufficient to maintain operator skills.

- If practices decide to perform spirometry on young children, computer software providing incentive graphics to encourage children to perform the test are essential e.g. an image of a lighted candle to blow out, or a fairground 'hammer and gong'.

Recommendation: Spirometer manufacturers or agents should provide a report or publication showing that their instrument complies with ATS or ATS/ERS specifications. ${ }^{6}$

\section{Provision of spirometry; primary care or laboratory?}

Whilst an expert service may be ideal, this may not be a practical solution for many primary care providers. Furthermore, given the prevalence of respiratory disease managed in primary care, there is a role for practice-based spirometry. This should include rigorous, assessed training for personnel, and high levels of quality control. The decision to undertake a practice-based spirometry service should include consideration of the realistic costs (both capital and revenue) necessary to deliver a service of reliably good quality.

Recommendation: Tests of pulmonary function require maximal subject co-operation and effort and therefore should be administered by trained, competent (accredited) and experienced personnel who are able to assess the correct performance of the test by the patient and the quality of the resultant tracings before the patient leaves the premises. This will avoid the need for patient recall if problems are identified during interpretation at a later stage.22

Recommendation: Commissioners should ensure that local providers of spirometry meet quality assured standards. If the service is not able to be provided in a local primary care setting, alternatives should be commissioned to ensure patient safety. These could include utilisation of locally commissioned practice spirometry services or provision of a fully interpreted spirometry service with trained and experienced technicians. ${ }^{22,32,40,41}$

Table 1. Choosing a spirometer: Features and Considerations.

\begin{tabular}{|c|c|c|}
\hline Essential features & Desirable features & Considerations \\
\hline Volume range: 0 to 8 litres $(+/-3 \%$ or $50 \mathrm{ml})$ & \multirow{2}{*}{$\begin{array}{l}\text { Display shows real-time, volume-time } \\
\text { graphic and/or flow-volume curve * }\end{array}$} & Costs (capital and revenue) \\
\hline Flow range: -12 to $+12 \mathrm{~L} / \mathrm{s}(+/-5 \%$ or $0.2 \mathrm{~L} / \mathrm{s})$ & & Reliability and accuracy \\
\hline Resistance: below $0.15 \mathrm{kPa}$ per L/s (0 to $12 \mathrm{~L} / \mathrm{s}$ ) & \multirow{2}{*}{$\begin{array}{l}\text { Hardcopy printout of all efforts produced } \\
\text { (directly to printer or via personal } \\
\text { computer) }\end{array}$} & Complexity and ease of use (hardware and \\
\hline Must measure/calculate: $\mathrm{FEV}_{1}, \mathrm{FVC}, \mathrm{FEV}_{1} / \mathrm{FVC}$, & & software) \\
\hline $\mathrm{FEV}_{1} N \mathrm{NC}$ & Measures peak expiratory flow (PEF) & Portability, size, robustness \\
\hline \multirow{2}{*}{$\begin{array}{l}\text { Calibration: } 1-L \text { or } 3-L \text { syringe (with verification } \\
\text { that test is acceptable) }\end{array}$} & \multirow{2}{*}{ Quality acceptance criteria. } & Ease of cleaning; infection control measures \\
\hline & & Quality of the software \\
\hline
\end{tabular}

* Number-only displays are only of use for monitoring after reliable quality spirometry has been performed. 


\section{Quality control and governance}

Calibration or verification with an annually certificated calibration syringe needs to take place at every spirometry session, or after every 10 patients for a busy service. The weekly use of biological controls (achieved by the use of a stable healthy individual ${ }^{42}$ as detailed in Box 1 ) is a less reliable method of checking long term stability of spirometers.

Careful and regular use of a spirometer should make the user familiar with common warning signs about its performance. Attention should be paid to unusual, sudden changes in performance. Keeping a simple log of problems is usually a good way to recognise faults that may develop or that may be common to that device.

The spirometer should be carefully checked after cleaning. Errors can occur at this time due to water penetration or faulty re-assembly. Any damage, breaks or dropping of devices will require checks to be made to confirm good performance.

Recording of test conditions is vital for accurate and repeatable spirometry. Expired gas should be corrected to body temperature and humidity (BTPS);, 6,43 the manufacturer should provide details of how this is determined. The patient's medication history prior to measurement, the time after their last meal, their position (preferably sitting) and patient cooperation should all be recorded. An example of a template that can be used for this purpose is shown online as Appendix 1 (available at www.thepcrj.org). This could be attached to each spirometry result to assist interpretation.

\section{Infection prevention and control}

Recorded cases of infection transmission from spirometry equipment, between patients, and between patients and staff, are rare. ${ }^{44,45}$ Cross contamination through mucosal contact with spirometry equipment and aerosolisation of infective

\section{Box 1: Determining the normal range for a biological}

\section{control.}

- The person used as a biological control must be healthy and free of known respiratory disease

- Record your own spirometry every day (or that of a colleague if you have a respiratory condition) at the same time of day, on the same spirometer for 14 days. You will need a minimum of 10 recordings.

- Calculate the mean (average) for each spirometry parameter: i.e. add up all the readings for that parameter and divide by the number of recordings (e.g. mean $3.60 \mathrm{~L}$ ).

- Now calculate $2.5 \%$ of the mean (i.e. $3.6 \times 0.025=0.09 \mathrm{~L}$ ):

- Finally, obtain the normal range for repeated measurements by adding and subtracting this $2.5 \%$ value to the mean value (i.e. $3.6-0.09=3.51 \mathrm{~L}$; and $3.6+0.09=3.69 \mathrm{~L}$ so the acceptable range for the person tested would be $3.51 \mathrm{~L}$ to $3.69 \mathrm{~L}$ )

You can now use this person to check that the spirometer readings fall within this range to verify the accuracy of your spirometer on a weekly basis.

particles during forced expiratory manoeuvres are the main potential sources of infection. ${ }^{46,47}$ Measures to reduce the risk to both staff and patients ${ }^{48}$ are summarised in Table 2.

Cross infection is more likely when inspiratory manoeuvres are undertaken. This is not routinely undertaken in primary care settings, but it can be difficult to prevent accidental inhalation through the equipment. Therefore disposable, valved mouthpieces should be used. If inspiratory manoeuvres are undertaken, disposable antibacterial and viral filters must be used.

\section{Indications and contraindications}

Clinical indications for spirometry

Respiratory symptoms are often non-specific. The indications

Table 2. Infection prevention and control measures. (Adapted from ref 6).

\begin{tabular}{|c|c|c|}
\hline Infection transmission & Likely sources of contamination & Risk reduction \\
\hline $\begin{array}{l}\text { Direct contact - URTI, enteric infections, } \\
\text { blood borne infection (from bleeding } \\
\text { gums or mouth ulcers / sores) }\end{array}$ & $\begin{array}{l}\text { - Mouthpieces } \\
\text { - } \quad \text { Nose clips } \\
\text { - Tubing, flow heads }\end{array}$ & $\begin{array}{l}\text { Do not test patients with known infection, if possible. } \\
\text { - If tests are necessary, test potentially infectious } \\
\text { patients at the end of a session and dismantle and } \\
\text { sterilise equipment after use } \\
\text { - Test vulnerable patients (e.g. immunocompromised) } \\
\text { at the start of a session on newly sterilised equipment }\end{array}$ \\
\hline \multirow[t]{4}{*}{$\begin{array}{l}\text { Indirect contact (aerosol droplet) - TB, } \\
\text { viral infections, opportunistic infections, } \\
\text { nosocomial pneumonia }\end{array}$} & $\begin{array}{l}\text { - } \text { Mouthpieces } \\
\text { - Tubing }\end{array}$ & $\begin{array}{l}\text { For infection control in these patients, use disposable } \\
\text { nose clips and valved mouthpieces with an antibacterial } \\
\text { filter. }\end{array}$ \\
\hline & & $\begin{array}{l}\text { - Wash hands before and after handling equipment and } \\
\text { between patients }\end{array}$ \\
\hline & & $\begin{array}{l}\text { - Use disposable plastic gloves for handling mouthpieces } \\
\text { and potentially contaminated surfaces }\end{array}$ \\
\hline & & $\begin{array}{l}\text { Wash surfaces in contact with mucous membranes in } \\
\text { hot soapy water prior to decontamination and } \\
\text { disinfection. }\end{array}$ \\
\hline
\end{tabular}




\section{Box 2: Indications for spirometry.}

Spirometry (in addition to other investigations) should be considered for:

- Patients presenting with undiagnosed respiratory symptoms:

- Dyspnoea

- Wheeze

- Cough

- Patients with suspected COPD, in particular those with a positive smoking history and:-

- Increasing age

- Chronic cough

- Breathlessness on exertion, and

- Daily wheezing ${ }^{52}$

- History of recurrent winter 'chest infections' ${ }^{53}$

- Diagnosis of COPD

- $\quad$ *post-bronchodilator spirometry is required for QOF payment in the UK

- Monitoring patients with established COPD

- Diagnosis of asthma ${ }^{54}$

*As stated in the NICE COPD Guideline:8 "In most patients, routine spirometric reversibility testing is not necessary as a part of the diagnostic process or to plan initial therapy with bronchodilators or corticosteroids. Making a diagnosis relies on clinical judgement based on a combination of history, physical examination and confirmation of the presence of airflow obstruction using spirometry."

for spirometry are summarised in Box 2.

Spirometry is an effective test for differentiating obstructive from non-respiratory disease. True restrictive ventilatory defects i.e. conditions leading to an abnormally low total lung capacity (TLC) - are uncommon. An analysis of the Health Survey for England 1995-1996 data found that a 'restrictive pattern' compatible with a restrictive ventilatory defect occurred exclusively in $2.5 \%$ of symptomatic subjects and/or smokers (Personal communication, Philip Quanjer). Therefore this condition should only be considered if there is clinical evidence of it. Restrictive disease cannot be diagnosed solely by spirometry, but can be excluded in the case of a normal vital capacity (VC).

Recently there has been a great deal of interest in screening for early, asymptomatic COPD in primary care. ${ }^{49}$ Focussing spirometry screening on smokers with chronic cough has been shown to be effective. ${ }^{31}$ Questionnaires are also an effective approach to screening..$^{50.53}$

In the case of asthma, the British ${ }^{9}$ and International ${ }^{54}$ guidelines emphasise the use of spirometry as part of the diagnostic process. Since many of these patients are children, there will be additional requirements for staff training for this purpose, including the use of graphic incentives during the test process.

\section{Contraindications to spirometry}

Spirometry is safe and there are no absolute contraindications. There are some relative contraindications ${ }^{55}$ (see Table 3 ) where it might be advisable to delay testing or to seek advice from the local pulmonary function laboratory.

Children under the age of five years are unlikely to be able to produce reliable spirometry and interpretation of the results can be complex. ${ }^{9}$ Referral to a specialist respiratory unit may be necessary.

\section{Conducting the spirometry test}

Competent spirometry requires adequate achievement of the following:

- Preparation of the equipment and patient

- Performance of the test to meet national/international standards

- Production of accurate results with reference values

- Interpretation of the results.

\section{Preparation of the equipment}

The spirometer should be calibrated or verified so that it measures accurately, and its software configured so that meaningful results can be produced. Adequate procedures for infection control and maintenance are essential.

\section{Preparation of the patient}

The patient needs to be prepared in advance in terms of criteria that can affect the results (e.g. tight clothing, same time of day if follow-up test, large meals, medication - if reversibility tests are planned). The patient should be seated for safety and any contraindications ruled out before progressing with the tests (see Table 3). Any unusual circumstances, conditions and events should also be recorded. Full bladders and stress incontinence may cause underperformance.

\section{Performing the test}

Some key points for performing spirometry and instructing a patient to perform a test using a forced expiratory manoeuvre ${ }^{24,56,57}$ are shown below:

i) Measure the patient's height*and weight, and enter their date of birth and gender into the spirometer software. (*Self-reported heights should not be used. ${ }^{58-60}$ )

ii) Attach a new, disposable, one-way mouthpiece to the spirometer. (If the patient has an infection or if inspiratory manoeuvres are planned, a bacterial filter must be used.)

iii) Place a nose clip on the patient, or instruct him/her to pinch the nose closed.

iv) Instruct the patient to breathe in and out normally and then to inhale deeply through their mouth until the lungs feel absolutely full, and then while holding their breath, to seal their lips tightly around the mouthpiece.

v) With the minimum of delay between inhalation and exhalation, instruct the patient to blow the air out through the mouthpiece as forcefully and as fast as possible, using maximum effort, until there is no more air left to expel. Verbally encourage the patient to "keep blowing and keep blowing" until there is no more. (See below for instructions 
ML Levy et al.

Table 3. Relative contraindications to spirometry. (Adapted from ref 6).

\begin{tabular}{|c|c|}
\hline Relative contraindication & Rationale \\
\hline \multirow[t]{2}{*}{ Known or suspected respiratory infection } & Potential contamination of equipment and cross infection risk \\
\hline & Results unlikely to be meaningful, reliable or reproducible \\
\hline \multirow[t]{2}{*}{ Haemoptysis of unknown origin } & Exacerbation of the problem and possible major haemorrhage. \\
\hline & $\begin{array}{l}\text { Possible active pulmonary tuberculosis leading to contamination of equipment and cross } \\
\text { infection risk }\end{array}$ \\
\hline Pneumothorax & Aggravation of the condition \\
\hline $\begin{array}{l}\text { Unstable cardiovascular status: recent (within } 1 \\
\text { month) myocardial infarction, uncontrolled } \\
\text { hypertension or pulmonary embolism }\end{array}$ & Forced expiration can worsen angina or cause potentially dangerous blood pressure changes \\
\hline $\begin{array}{l}\text { Uncontrolled hypertension or history of } \\
\text { haemorrhagic cerebrovascular event }\end{array}$ & Precipitation of cerebral bleed \\
\hline Recent thoracic, abdominal or eye surgery & Pain or incisional hernias. Raised intraocular pressure post ophthalmic surgery undesirable \\
\hline Nausea, vomiting or pain & Effect on patient's ability to co-operate and perform the test \\
\hline Confusion, dementia & Unlikely to be able to comply with instructions \\
\hline
\end{tabular}

\section{for performing a slow/relaxed VC manoeuvre.)}

vi) Carefully observe the patient throughout the procedure to make sure a good mouth seal around the mouthpiece is achieved, that there isn't a 'slow start' or any pauses while blowing, and that the patient has not coughed.

vii) The patient should be encouraged to continue blowing continuously, without taking additional breaths, until a plateau has been reached on the volume/time graph. The end of the test should show a smooth plateau free from artefacts such as intermittent inhalation.

viii) The spirometer should be set to indicate whether the tests meet the current standards for repeatability. Currently this means that the two largest FEV 1 and FVC (or other VC) readings must be within $150 \mathrm{~mL}$ of each other.

It is good practice to do an initial slow (or relaxed) vital capacity manoeuvre. To do this, substitute the following instruction for point v) above:

With the minimum of delay between inhalation and exhalation, instruct the patient to blow the air out through the mouthpiece in a slow relaxed manner, continuously, without taking another breath, until there is no more air left to expel. Verbally encourage the patient to "keep blowing and keep blowing" until there is no more.

Whilst spirometry software will indicate whether many of the repeatability criteria are met, the operator must be trained to observe whether the test has been performed correctly. For a further example of instruction for patients see http://www.spirxpert.com/performing2.htm.

\section{Interpretation}

What follows is a detailed explanation of spirometry interpretation. This is intended for those practitioners who have had training in performing and interpreting spirometry, as well as those clinicians (such as GPs or Nurses with a special interest in respiratory disease) who are practising at a more advanced level. For those health professionals wishing to access summary information, the GPIAG opinion sheet ${ }^{61}$ and the versions published on the GOLD website ${ }^{56,57}$ may suffice.

\section{Reference values}

Pulmonary function tests are not pathognomonic of any particular disease; interpretation begins with a differential diagnosis defining the pre-test probability of disease, which is assessed clinically. Results are then compared with reference values, appropriate for age, height, gender and ethnicity.

The European Community for Steel and Coal (ECSC) reference values ${ }^{43}$ are most commonly used in European populations. Other equations are those from Hankinson ${ }^{62}$ (for white, African and Latin-American people age 8-80 yrs), Stanojevic ${ }^{63}$ (for white people age 4-80 yrs), and Falaschetti ${ }^{64}$ (for white people age 16-95 yrs). It is customary to use 'correction factors' (i.e. to multiply with derived indices) for other ethnic groups (see Table 5) but these are just 'ballpark' figures that correct for the average predicted value and not for the clinically more important Lower Limit of Normal (LLN). Free software with documentation for all ethnic groups is available. ${ }^{65}$ Whichever reference values are chosen, it is common practice to regard values below the 5 th percentile the LLN - as abnormally low. ${ }^{66}$

\section{Indices}

The spirometry indices used in primary care should be limited to a few key measurements, as detailed in Table 4. The $\mathrm{FEV}_{1} / \mathrm{slow}$ vital capacity (SVC), $\mathrm{FEV}_{1} / \mathrm{FVC}$, or $\mathrm{FEV}_{1} /$ inspiratory 
Table 4. Spirometry indices (Common indices used in primary care are listed in this table, in addition to some that might be reported by a specialist service providing spirometry).

\begin{tabular}{|c|c|}
\hline PEF & $\begin{array}{l}\text { Peak expiratory flow is the measurement of fastest flow measured by either a spirometer or peak flow meter. Because of } \\
\text { equipment design these values vary from device to device and therefore, repeated PEF measurements should be done on the same } \\
\text { device. }\end{array}$ \\
\hline FET & Forced expiratory time is the total time it takes for a patient to complete their exhalation in a FVC manoeuvre. \\
\hline $\mathrm{FEV}_{1}$ & Forced expiratory volume in 1 second is the amount of air blown out fast in the first second following a maximal inhalation. \\
\hline FVC* & $\begin{array}{l}\text { Forced vital capacity is the amount of air blown out fast following a maximal inhalation (i.e. at total lung capacity) to empty } \\
\text { (residual volume) in up to } 12 \text { seconds. }\end{array}$ \\
\hline IVC* & $\begin{array}{l}\text { Inspiratory vital capacity is the inspired volume after a maximal exhalation. This is not usually performed in primary care, and if } \\
\text { measured must always be done using a filter. }\end{array}$ \\
\hline SVC* & $\begin{array}{l}\text { Relaxed or 'slow' vital capacity is the total expired volume from a point of maximum inhalation (at total lung capacity) by a } \\
\text { "gradual exhalation but with some pace" to being 'empty' at residual volume. }\end{array}$ \\
\hline $\mathrm{FEF}_{25-75}, \mathrm{MEF}_{50}$ & $\begin{array}{l}\text { This is the mid expiratory flow between } 25-75 \% \text { of an expired blow (or } 50 \% \text { respectively) and is an indication of flow in the } \\
\text { middle of an expiratory flow-volume curve. It used to be regarded as a more sensitive index of airflow obstruction. However, } \\
\text { the reference ranges are often too great for these numbers to be helpful. 'Shape recognition' of a flow-volume curve is a more } \\
\text { powerful tool to describe the presence of the obstruction. }\end{array}$ \\
\hline & his is the volume of gas remaining in the lung at the end of a full expiration. Only available in a lung function laboratory. \\
\hline
\end{tabular}

* While the IVC is the best measure, this is not often performed in primary care. In primary care the SVC should always be measured, as well as the FVC

The ratio ( $F E V_{1} N C$ ) should be calculated using whichever is the higher of the VC measurements obtained (FVC or SVC).

vital capacity (IVC) ratios are used to determine whether there is airways obstruction, and FEV 1 expressed as a percentage of the predicted/reference value is used to assess the severity of the airways obstruction (see Tables 5 and 6). The IVC, which is the gold standard vital capacity test, should only be performed in facilities where antibacterial filters are used, in order to reduce the risk of transmission of infection.

\section{Using the indices - interpreting the results}

\section{Ratio of FEV 1 to vital capacity}

The ratio of $\mathrm{FEV}_{1}$ to all three of the vital capacity measurements (i.e. $\mathrm{FEV}_{1} / \mathrm{IVC}, \mathrm{FEV}_{1} / \mathrm{SVC}, \mathrm{FEV} / \mathrm{FVC}$ ) identifies the presence of airways obstruction - the $F E V_{1} / I V C$ being the most and the $\mathrm{FEV}_{1} / \mathrm{FVC}$ the least reliable of the three. While any of these ratios may be used in practice, it is uncommon for the inspiratory manoeuvre (which provides the most reliable measure of vital capacity) to be performed in primary care. Furthermore, while it is good practice, an SVC manoeuvre is not always performed in primary care. In primary care, therefore, whilst the $\mathrm{FEV}_{1} / \mathrm{SVC}$ should be preferred, in the absence of a slow manoeuvre the $\mathrm{FEV}_{1} / \mathrm{FVC}$ is the next best. If both SVC and FVC have been determined, use the largest one for the $\mathrm{FEV}_{1} / \mathrm{NC}$ ratio.

Recommendation: In primary care the SVC should always be measured, as well as the FVC. The ratio $\left(F E V_{1} / \mathrm{VC}\right)$ should be calculated using whichever is the higher of the VC measurements obtained (FVC or SVC).

Percent predicted and 'normal distribution' of test results The ATS and ERS ${ }^{43,66,67}$ recommend that an $\mathrm{FEV}_{1} / \mathrm{IVC}, \mathrm{FEV}_{1} /$ $\mathrm{FVC}$ or $\mathrm{FEV}_{1} / \mathrm{SVC}$ ratio below the lower limit for age, height, sex and ethnic group is the best indicator of the
Table 5. Adjusting Caucasian reference values to other ethnic groups. To apply these, multiply FEV $\mathrm{V}_{1}$ and FVC by the factors. (Modified from ref 4).

\begin{tabular}{lll} 
Population & FEV $_{1}$ & FVC \\
\hline Hong Kong Chinese & 1.0 & 1.0 \\
Japanese American & 0.89 & - \\
Polynesian & 0.9 & 0.9 \\
N. Indian and Pakistani & 0.9 & 0.9 \\
S. Indian, African & 0.87 & 0.87
\end{tabular}

Table 6. Severity of airway obstruction based on the $\mathrm{FEV}_{1}$ as a percentage of the predicted/reference value.

\begin{tabular}{ll} 
Degree of severity & $\mathrm{FEV}_{1} \%$ predicted/reference value \\
\hline Mild & $>80$ \\
Moderate & $50-79$ \\
Severe & $30-49$ \\
Very severe & $<30$
\end{tabular}

presence of any airways obstruction. In agreement with this recommendation, the GOLD Guidelines ${ }^{10}$ - which originally recommended an $\mathrm{FEV}_{1} / \mathrm{FVC}$ ratio below 0.70 as indicative of obstructive lung disease - state:

"...because the process of aging does affect lung volumes, the use of a fixed ratio may result in over diagnosis of COPD in the elderly, especially of mild disease. Using the lower limit of normal (LLN) values for FEV $1 / F V C_{\text {, that }}$ are based on the normal distribution and classify the bottom $5 \%$ of the healthy population as abnormal, is one way to minimize the potential misclassification". 
In keeping with the ATS and ERS recommendations - in order to avoid over-diagnosing (and therefore over-treating) elderly patients, and under-diagnosing younger patients - the GOLD guidelines ${ }^{10}$ now state that:

"...many experts recommend use of the lower limit of normal for each population".

There is extensive evidence and argument that interpretation of pulmonary function tests should take into account the 'distribution of normal' test results in a population and thus inevitably rely on the lower limit of normal. This precludes the use of a fixed cut-off irrespective of age, height, gender and ethnic group. 62,64,65,67,68-81

Recommendation: Interpretation of pulmonary function tests should take into account the distribution of 'normal' test results in a population and will thus inevitably rely on the lower limit of normal (LLN), precluding the use of a fixed cut-off irrespective of age, height, gender and ethnic group. ${ }^{64,68-81}$ Implementation of this methodology will avoid over-diagnosing (and therefore overtreating) elderly patients, and under-diagnosing younger patients.

\section{Standardised residuals}

An alternative to the use of 'percent predicted' for reporting spirometry results is to encourage the use of standardised residuals $(\mathrm{SR})^{6,68}$ The standardised residual (also called z-score or standard deviation score) is the difference between the observed and predicted value divided by the standard deviation of the predicted value. In a healthy population $95 \%$ of the measured values should fall between a standardised residual of -2 and +2 , and $90 \%$ should fall between -1.64 and +1.64 .

\section{Forced expiratory volume in six seconds (FEV6)}

There has been recent research interest in the use of the FEV 6 in primary care cas-84 $^{6}$ and this is discussed in the GOLD guidelines. ${ }^{10,56}$ However, at the current time we do not see a clear physiological or clinical use for such a parameter. In the case of diagnostic spirometry, we believe the more accurate FVC to be a better reflection of lung function. The reasons for this stance are as follows:

Literature on the $\mathrm{FEV}_{6}$ shows that for many people with no lung disease or mild lung disease, the $\mathrm{FEV}_{6}$ will be the same as the FVC. However, for those with more significant disease the $\mathrm{FEV}_{6}$ will underestimate airway obstruction. The $\mathrm{FEV}_{6}$ was introduced to ensure that people tried to exhale for at least 6 seconds so as to prevent underestimating the FVC. While this period is no problem at all for patients with airway obstruction, it is unattainable for many healthy people, particularly young ones; most children and adolescents can exhale a full VC in less than 2 seconds. The requirement for spirometry is that people exhale fully and that this shows up in a volume-time plateau. Whether this occurs within or after 6 seconds is not relevant. In patients with severe airway obstruction the expiratory manoeuvre should not be extended beyond 10-15 seconds.

Recommendation: The person performing a spirometry test must ensure the patient exhales fully and that this is demonstrated on the graph showing a volume-time plateau.

\section{Report format}

As presentation of spirometry results varies from one manufacturer to another, it seems sensible for these to be reported in a uniform manner. For example, presentation of results could include figures related to the indices, tabulated by the pre- and post-bronchodilator values listed under the headings of 'Actual', 'Predicted', lower limit of normal (LLN), standard deviation score (SDS) and the level of severity, together with a graphic representation. For an example of a suggested output see Appendix 2, available at www.thepcrj.org.

Recommendation: Spirometry reporting across health care communities should be provided in an agreed and uniform manner, ideally involving use of FEV $1, F V C$ or SVC and using data highlighting lower limit of normal values.

\section{Diagnostic considerations and timing}

Due consideration should be given to the consequences of a false-positive or false-negative diagnosis; recent bronchodilator use and bronchodilator responsiveness should be taken into account and documented on the trace of the test. ${ }^{85}$ Using the stepwise approach shown in Figure 1 may help avoid over-diagnosis. ${ }^{86}$

Diagnoses should be based on prior evidence of disease, clinical symptoms and signs, and good quality spirometry. A diagnosis of a restrictive ventilatory defect requires referral for measurement of the TLC in a specialised laboratory; the centre box in Figure 1 has been shown to lead to high sensitivity and high specificity, ${ }^{86}$ and helps to limit unnecessary referrals. (The sensitivity of a test is the probability that the test will be positive when given to a group of patients with the disease. The specificity of a test is the probability that the test will be negative among patients who do not have the disease.)

Spirometric tests lead to the following patterns: obstructive, restrictive and mixed abnormalities.

[In this section, for simplicity, reference is made to the VC by this we mean the FVC, SVC or IVC, whichever is used in the particular situation where the spirometry is performed.]

\section{Obstructive abnormalities}

A reduction in maximum expiratory airflow relative to the maximum volume that can be expelled from the lung (the VC) reflects an obstructive ventilatory defect due to narrowed airways. In practice, the presence of airway obstruction is judged from the $\mathrm{FEV}_{1} \mathrm{NC}$ ratio.

Several organisations sought to simplify the diagnosis of airflow limitation by replacing the LLN with a fixed cut-off of 


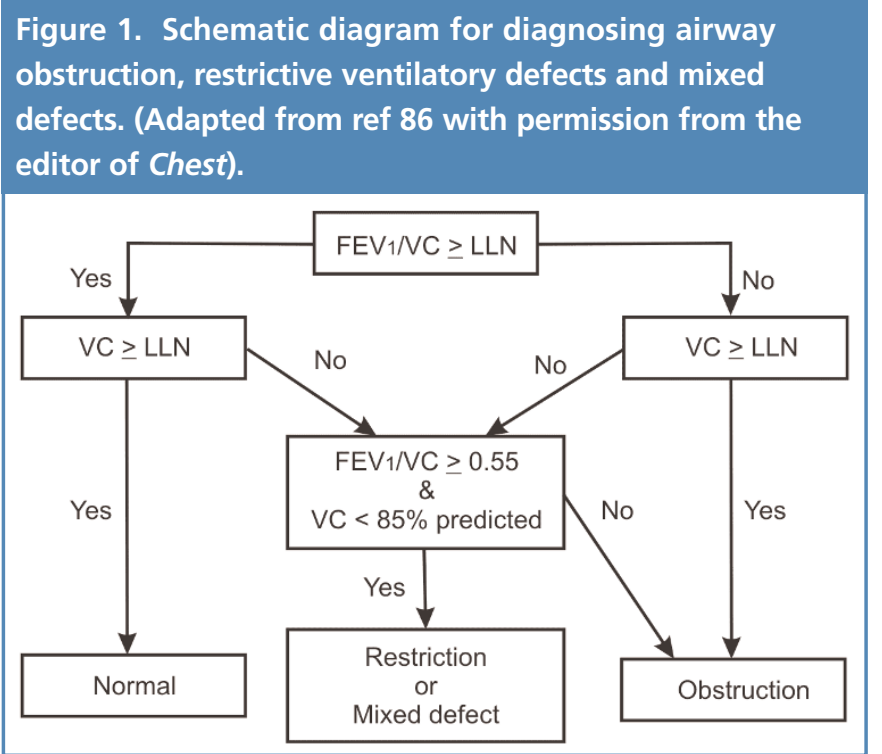

0.70..$^{8,10,87,88}$ However, as mentioned above, since the $\mathrm{FEV}_{1} \mathrm{NC}$ ratio is dependent on age, height and sex, this leads to about $100 \%$ over-diagnosis of obstructive lung disease in elderly subjects, and to under-diagnosis in young subjects. ${ }^{64,66,69-81}$ Therefore, the presence of obstructive lung disease should be based on an $\mathrm{FEV}_{1} \mathrm{NC}$ ratio below the LLN.

As the IVC is less affected by airway obstruction than the FVC or SVC, the Tiffeneau index ( $\mathrm{FEV}_{1} / \mathrm{IVC}$ ) is the preferred index in laboratories that routinely utilise inspiratory manoeuvres. It identifies more cases of airway obstruction than the forced expiratory ratio (FEV $1 / F V C) .^{66,89,90}$ However, in order to avoid cross-contamination the IVC is less practical in primary care, and as stated above, the best alternative ratio is the $\mathrm{FEV}_{1} / \mathrm{SVC}$.

Diminished expiratory flow towards the end of the forced expiratory manoeuvre, due to narrowing in the smallest airways and leading to a concave expiratory flow-volume curve, is thought to be the first sign of chronic obstructive lung disease. Therefore, flow measured after $75 \%$ of the FVC has been exhaled $\left(\mathrm{FEF}_{75}\right)$, or mean expiratory flow between $25 \%$ and $75 \%$ of the FVC (FEF 25-75) have been used to diagnose airway obstruction. These were not found to have advantages over the $\mathrm{FEV}_{1} \mathrm{NC}$ ratio. In advanced obstructive lung disease the $\mathrm{VC}$ will be reduced, but not in proportion to the FEV 1 .

\section{Restrictive and mixed abnormalities}

The results of pulmonary function tests are highly dependent on patient co-operation. Premature termination of the FVC manoeuvre, or failure to take a maximal inhalation, can result in a high $\mathrm{FEV}_{1} / \mathrm{FVC}$ ratio. A normal or high $\mathrm{FEV}_{1} / \mathrm{FVC}$ ratio when the FVC is too low is most often due to incomplete inhalation or exhalation. ${ }^{66}$

A TLC below its LLN is the hallmark of a restrictive ventilatory defect. ${ }^{66}$ If not accompanied by airway obstruction the following pattern of spirometry is observed:

- normal or increased $\mathrm{FEV}_{1} N \mathrm{NC}^{*}$ ratio

- low VC, and

- a convex expiratory flow-volume curve.

*(VC may be FVC, SVC or IVC)

As explained above, however, this pattern of findings is usually due to suboptimal performance of the inspiratory or expiratory manoeuvre. ${ }^{66}$

A true restrictive ventilatory defect may occur concurrently with airway obstruction if the $\mathrm{TLC}$ and $\mathrm{FEV}_{1} \mathrm{NC}$ are both below their LLN. This represents a mixed ventilatory defect, i.e. restriction and airway obstruction. ${ }^{66}$ This diagnosis cannot be made on the basis of spirometry alone because the VC may be reduced due to airway obstruction without restriction. If tests are satisfactorily performed and the TLC is unknown, (which is often the case in the primary care setting), a restrictive ventilatory defect should only be considered if:

- $\mathrm{FEV}_{1} \mathrm{NC}>0.55$, and

- FVC $<85 \%$ predicted. $^{86}$

In these cases, if there is clinical evidence for restrictive lung disease, referral to a pulmonary function laboratory with facilities to measure TLC and gas transfer is recommended.

Figure 2 shows a summary of the types of ventilatory defects and their diagnoses seen on flow-volume spirometry curves.

\section{Upper and central airway obstruction}

Where inspiratory curves are included, in rare cases the flowvolume curves may be indicative of central and upper airway obstruction (Figure 3). Referral to secondary care for confirmation of the diagnosis is recommended.

\section{Severity of impairment}

Lung function impairment has bearing on exercise capacity, disability and employment compensation, quality of life, morbidity and mortality. ${ }^{91}$ In several studies, FEV 1 , postbronchodilator $\mathrm{FEV}_{1}$, post-bronchodilator $\mathrm{FEV}_{1}$ percent predicted and $\mathrm{FEV}_{1} /$ height $^{2}$ were found to correlate best with all-cause mortality. ${ }^{92-104}$

For general purposes the severity of lung function impairment is based on $\mathrm{FEV}_{1}$ percent predicted (Table 5), the scaling of which is arbitrary. ${ }^{66}$ The scaling does not apply to upper airway obstruction; also, FEV 1 percent predicted correlates rather poorly with respiratory symptoms and quality of life. ${ }^{105-107}$

\section{Bronchodilator response:}

As stated in the NICE COPD Guideline ${ }^{8}$ :

"In most patients, routine spirometric reversibility testing is not necessary as a part of the diagnostic process or to plan initial therapy with bronchodilators or corticosteroids. Making a diagnosis relies on clinical judgement based on a combination of history, physical examination and confirmation of the presence of airflow obstruction using spirometry." 
ML Levy et al.

Figure 2. Examples of expiratory flow-volume curves from a healthy subject, and in obstructive, restrictive and mixed pulmonary defects. Confirmation of restrictive defects (quite rare in general practice) requires measurement of the total lung capacity in a pulmonary function laboratory (right panel). (Reproduced from Quanjer et al..$^{43}$ with permission from the editor of the European Respiratory Journal).
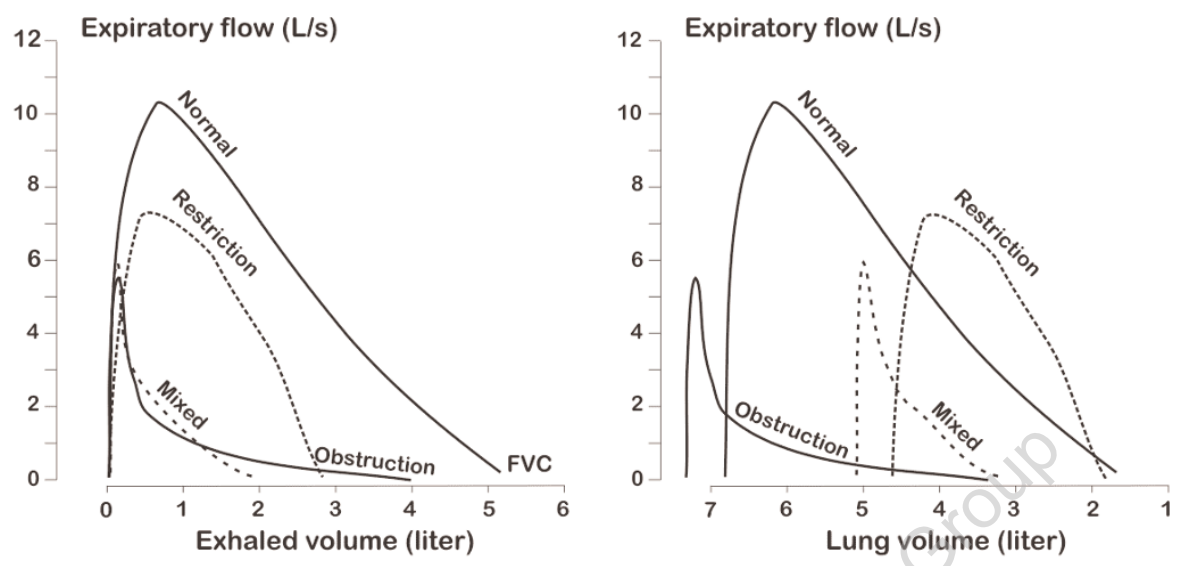

Figure 3. Examples of fixed large airway obstruction (left), variable large extrathoracic airway obstruction (middle) and variable intrathoracic large airway obstruction (right). (Reproduced from Pellegrino et al. ${ }^{66}$ with permission from the editor of the European Respiratory Journal).
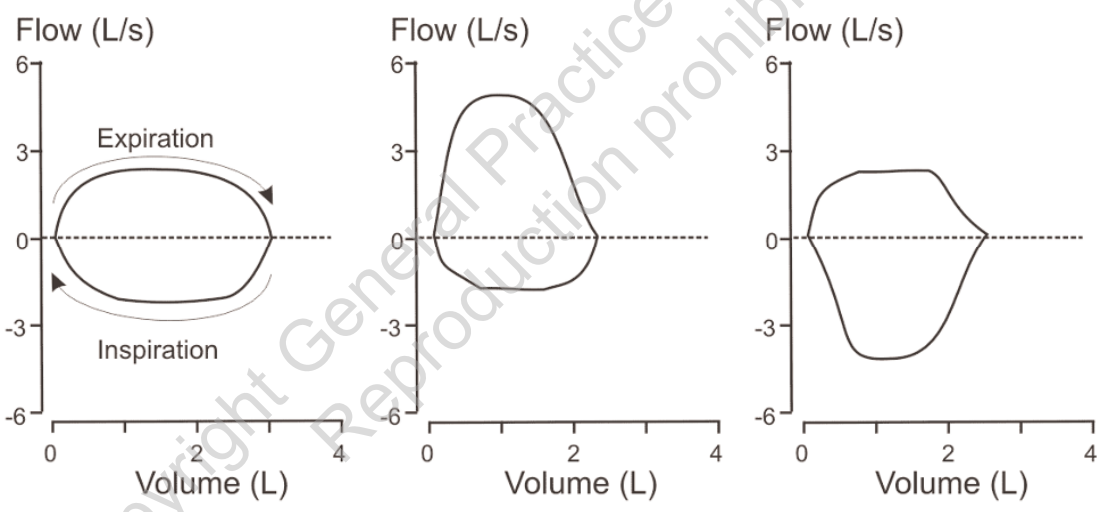

However, assessing the response to bronchodilator drugs is useful in assessing whether airway obstruction is reversible - a hallmark of asthma. Bronchodilator responsiveness is traditionally judged by an improvement in $\mathrm{FEV}_{1}$.

Airway patency varies due to the circadian rhythm in biological functions and, in disease, to fluctuations in the activity of the disease process. Hence the response to a bronchodilator drug is generally poorly reproducible. ${ }^{108-110}$ For the response to be regarded as positive it should exceed short term fluctuations in $\mathrm{FEV}_{1}$ and the response in a healthy population. The effects of anti-inflammatory drugs can be assessed after a few weeks' treatment, whereas the effects of drugs that solely relieve bronchomotor tone can be studied within 15-30 minutes of inhalation, e.g. four separate doses of $100 \mathrm{mcg}$ salbutamol by metered dose inhaler and spacer.

Bronchodilators do not reliably discriminate asthma from
COPD. ${ }^{108,110-116}$ Bronchodilator responsiveness is less in smokers than in non smokers, ${ }^{117,118}$ and correlates poorly with symptoms, ${ }^{119-122}$ prognosis and effects of treatment, ${ }^{109,122,123}$ and improvement in exercise capacity. ${ }^{124}$ Conversely, lack of a significant response in $\mathrm{FEV}_{1}$ can be associated with both significant improvements in resting and dynamic hyperinflation during exercise, and improvements in symptoms and exercise performance, particularly in severe COPD. ${ }^{125-132}$

According to most authors the improvement in $\mathrm{FEV}_{1}$ in adults, expressed in $\mathrm{mL}$, is independent of the baseline level. Hence, expressing the change as a percentage of the baseline $F E V_{1}$ exaggerates the response in those with the poorest $F E V_{1}$. Expressing the change in $\mathrm{FEV}_{1}$ post-bronchodilator as a percentage of the predicted value eliminates this problem and adjusts for differences in lung size. ${ }^{108,109,117} \mathrm{~A}$ change $>12 \%$ 
predicted and $>200 \mathrm{~mL}^{109,133-137}$ during a single test session is accepted as denoting a statistically significant improvement. One guideline ${ }^{8}$ suggested, "on an arbitrary basis", that $>400 \mathrm{~mL}$ could be adopted as a clinically significant improvement following bronchodilation; however, against the background of published results ${ }^{133-137}$ it seems that this level is very strict indeed. In a clinical database (Erasmus University Medical Centre, Lung Department, Rotterdam) of 4,352 patients tested pre- and postbronchodilator, a change in $\mathrm{FEV}_{1}$ exceeding $400 \mathrm{~mL}$ was observed in $3.35 \%$ of patients, and $>200 \mathrm{~mL}$ in $14.96 \%$ of patients. As children have smaller lungs it has been suggested that the $200 \mathrm{~mL}$ criterion should be dropped. ${ }^{135-137}$

\section{Recommendation: Post-bronchodilator}

spirometry:

i) In the case of airway obstruction it is good practice to include post-bronchodilator spirometry testing, especially in newlydiagnosed patients.

ii) In the case of diagnosis of COPD: postbronchodilator spirometry is recommended by the GOLD and ERS/ATS COPD guidelines and is required to satisfy the requirements of the UK payment system for GPs - the Quality Outcome Framework (QOF).

\section{Interpreting change}

Tracking lung function changes over time within an individual is often more valuable than comparisons with predicted values. In healthy adults the decline of pulmonary function with age is about 20-35 mL per year. This is far smaller than the reproducibility of measurements made the same day, weeks or months apart. Small systematic errors - e.g. due to calibration or use of different apparatus - easily exceed the small annual declines. ${ }^{138-140}$ Establishing whether a decline is abnormal therefore requires many measurements over a number of years. ${ }^{138,141}$

In patients with lung disease, variability in repeated measurements is larger than in healthy subjects, ${ }^{139,142,143}$ the coefficient of repeatability for $\mathrm{FEV}_{1}$ between two visits has been estimated at $320 \mathrm{~mL}$ for men and $240 \mathrm{~mL}$ for women. ${ }^{144}$ In another study, over $90 \%$ of participants had an inter-session difference of less than $225 \mathrm{~mL}$ in $\mathrm{FEV}_{1}$, and $325 \mathrm{~mL}$ in FVC, irrespective of the severity of obstruction. ${ }^{145}$ Therefore, in adults with lung disease, changes exceeding these figures are likely to be clinically meaningful.

\section{Referral}

In view of the unfavourable consequences for patients incorrectly diagnosed, whenever a primary care clinician is unsure of the diagnosis, referral is appropriate.

There are three clear situations in cases where abnormal primary care spirometry should prompt referral to specialist respiratory services for more detailed pulmonary function testing:
Recommendation: Where facilities to undertake or interpret spirometry are not available, or where clinicians feel uncertain in their diagnosis, referral to more specialised services is appropriate.

Recommendation: In cases where there is clinical and spirometric evidence for restrictive lung disease, referral to a pulmonary function laboratory with facilities to measure Total Lung Capacity (TLC) and gas transfer is recommended in order to confirm the diagnosis.

Recommendation: In cases where there is clinical or spirometric evidence of central or upper airway obstruction, referral to secondary care for confirmation of the diagnosis is recommended.

\section{Quality control and training}

Spirometric tests need to be administered by trained, experienced and preferably certified personnel. The European Respiratory Society is starting a certification programme for technicians and laboratories. Equipment, the administration of tests, the quality control of equipment and individual FVC manoeuvres, as well as the repeatability of $\mathrm{FEV}_{1}$ and FVC should comply with ATS/ERS recommendations. ${ }^{6}$

It is therefore highly recommended to use equipment that provides online feedback on within- and between-manoeuvre acceptability in accordance with ATS/ERS recommendations (see Table 7). In addition the software used should provide the LLN for FEV $1, F V C$ and $F E V_{1} / F V C$, since the diagnostic process should be based on the LLN (Figure 1), and on FEV 1 percent predicted for assessing the severity of airways obstruction ${ }^{6}$ (see Table 4).

The BLF survey concluded that primary care health professionals may have difficulty in acquiring enough expertise in differentiating these diseases. ${ }^{27}$ However, greater routine application for diagnostic purposes should enable trained primary care staff to gain the necessary experience, obviating the need for referral to services for appropriate testing and interpretation. Nevertheless, in the absence of adequately trained and experienced primary care personnel it would be appropriate for patients requiring spirometry to be referred for testing and interpretation.

\section{Over-reading services}

While there is no substitute for accredited training and demonstrated competence by people performing and interpreting spirometry, quality control would be of benefit in determining the need for remedial training. For example, practices may benefit from a spirometry 'over-reading' service, where reports are sent for expert review. This would facilitate quality control of spirometry tests and their interpretation.

The use of one expert computer system has proved disappointing, ${ }^{35}$ but this study did highlight that participating 


\section{Table 7. Summary of within- and between-manoeuvre acceptability criteria. Reproduced from Miller et al. ${ }^{6}$ with permission from the Editor of the European Respiratory Journal.}

\section{Within-manoeuvre criteria}

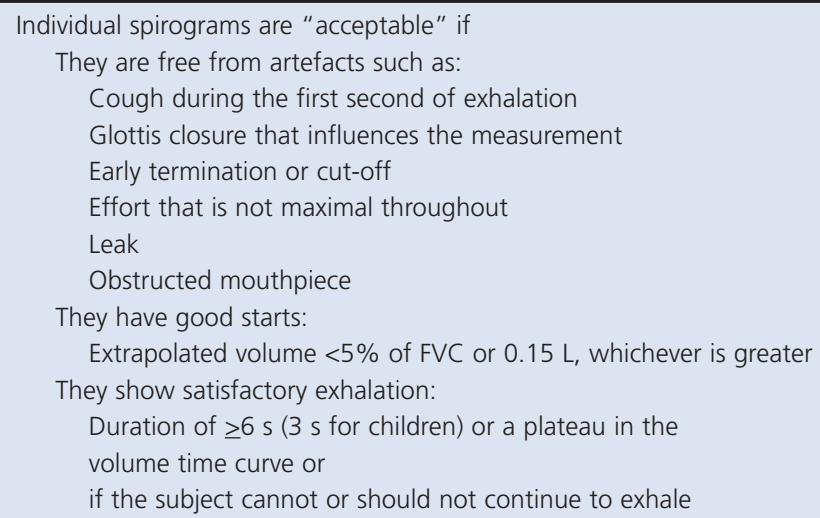

After three acceptable spirograms have been obtained, apply the following tests:

The two largest values of FVC must be within $0.150 \mathrm{~L}$ of each other The two largest values of $\mathrm{FEV}_{1}$ must be within $0.150 \mathrm{~L}$ of each other If both of these criteria are met, the test session may be concluded If both of these criteria are not met, continue testing until:

Both of the criteria are met with analysis of additional acceptable spirograms, or

A total of eight tests have been performed (optional), or

The patient/subject cannot or should not continue

Save, as a minimum, the three satisfactory manoeuvres

FVC: forced vital capacity; $\mathrm{FEV}_{1}$ : forced expiratory volume in one second For schoolchildren $(6-<12 \mathrm{yr})$ the acceptability criterion for FVC and FEV 1 should be 'within $5 \% \mathrm{FVC}$ or $<100 \mathrm{~mL}$ if FVC $<1000 \mathrm{~mL}$ '.

GPs failed to recognise poor spirometry technique in nearly $30 \%$ of cases studied. Clinical trials utilising centralised spirometry with training, technician accreditation and prompt feedback can improve the quality of data collected. ${ }^{146,147}$ Overreading services can therefore work as a quality assurance system within a health care community and possibly help to educate those involved in spirometry.

\section{Training and CPD recommendations}

\section{Minimum training requirement}

Spirometry training needs to include: awareness of the issues related to delivery of the service; competence in performing the measurements; and competence in interpreting and reporting of results. Some or all of these components may be required depending on the model of service delivered in primary care (see Boxes 3 and 4). Furthermore, these tasks may be performed by different individuals. The key issue is that these individuals should be trained to agreed national or international standards in order to perform the task.

A new ERS Task Force on spirometry training requirements

\section{Box 3: Basic training in spirometry.}

- Spirometry equipment

- calibration

- infection prevention and control measures

- Patient preparation

- indications and contraindications for spirometry

- accurate recording of height and weight

- checking and accurate recording of patient data

- How to conduct the test

- patient instructions and demonstrating the technique

- relaxed expiratory manoeuvres

- forced expiratory manoeuvres

- techniques for obtaining maximum effort from patients

- Test validity and reproducibility

- recognising non-reproducible results

- recognition of errors in technique, so the test can be repeated while the patient is still in the office.

- methods of correcting errors in technique

- Preparation of test results for reporting

- "Troubleshooting" and some understanding of the results to know that the test is satisfactory.

Box 4: Advanced training for primary care health

\section{professionals.}

Further education and training is needed for personnel responsible for interpreting spirometry results or for supervising others conducting the tests. This should include:

- Analysis of normal and abnormal patterns of spirometry

- Identification of errors in measurement and therefore that the test needs to be repeated.

- Supervision and quality control of others conducting spirometry tests

- Analysis of the relationship between patho-physiological changes in the lung and measurements obtained from dynamic lung volumes

- Ability to advise on subsequent patient management, based on the results of the spirometry.

will report in 2009. Discussions so far indicate the need for training - consisting of practical demonstration of competence in equipment maintenance and interpretation of results. $19,21,148,149$

In the UK, the Association for Respiratory Technology and Physiology (ARTP), in conjunction with the BTS through the BTS/ARTP Liaison Committee, have established a qualification to assess the competence of practitioners to perform such measurements. The ARTP/BTS Certificate in Spirometry has been introduced to give a recognised national qualification for those practitioners who complete an approved spirometry assessment course - and this ARTP/BTS course is also provided by Education for Health (see Box 5). The standards required for attainment of this certificate include a recommendation that 
Box 5: Education and Training organisations in the United Kingdom.

The following organisations offer ARTP approved spirometry training, resulting in the award of the ARTP/BTS Certificate

- $\quad$ ARTP/BTS Spirometry Courses and Assessment www.artpweb2.f9.co.uk

- Education for Health www.educationforhealth.org.uk (Spirometry module also accredited by the Open University - 15 level 2 CATS points)

- Primary Care Training Centre www.primarycaretraining.co.uk

Spirometry courses also available from:

- Respiratory Education UK www.respiratoryeduk.com (modules offered at diploma and degree level, accredited with University of Edge Hill)

- $\quad$ ERS European Spirometry Driving Licence which will be available within the next few years.

- Various spirometer manufacturers provide training. The quality of these varies - ideally they should be accredited by an appropriate body.

Basic training is often available locally

practitioners should have performed a minimum of 10-15 examples of varied disease types (obstructive, restrictive, errors). This is supported by one study which demonstrated a positive correlation between the number of spirometry tests performed and their acceptability. ${ }^{148}$ The qualification requires on-going validation of competency which has to be renewed every two years. According to expert opinion at least five tests a week (20/month) would be adequate to maintain competence in staff who had achieved initial competence. Indeed, if spirometry in primary care becomes more routine, there should be ample opportunity for a satisfactory level of experience and expertise to be maintained in primary care. However, this will mean continuous investment in those primary care settings where trained spirometry staff (e.g. practice nurses) may stay for only a limited number of years - thus making the system "unstable" with varying quality over time - with the resultant need to ensure ongoing training of newly-employed staff.

Currently there is no requirement for accreditation of primary care practitioners performing spirometry and there is a need for widespread and easy access to specific training, tailored to their needs. It is necessary that those providing this service should be fully trained to do so. There are appropriate training courses in different countries; in the UK, the type of qualification offered by the ARTP/BTS qualification is one that could be considered for primary care practitioners - hence the rationale for making this type of qualification more widely available through training organisations other than the ARTP in order to widen access so that more practitioners are trained to acceptable standards.

Recommendation: Training should be subject to assessment (according to national and international standards) and trainees should be able to demonstrate:

- sound knowledge of the role of spirometry in respiratory disease assessment

- competence and safe practice in both the technique and interpretation of spirometry. Recommendation: Health communities need to develop clear recommendations on minimum standards for spirometry testing, and systems to ensure that appropriate training, updating and quality assurance are maintained to minimise inappropriate diagnosis and interventions to the patient population.

\section{Conclusion}

These proposals and recommendations are designed to raise the standard of spirometry and respiratory diagnosis in primary care. We believe high standards of spirometry are achievable in most managed health care systems. The guidance requires strategic managerial input to implement within communities, and individual clinician responsibility to ensure standards are achieved.

We recognise that, in a laudable effort to simplify the diagnosis of COPD in elderly subjects, organisations abandoned the scientifically sound use of the lower limit of normal (LLN) and advocated the use of a fixed $\mathrm{FEV}_{1} / \mathrm{FVC}$ ratio to diagnose airway obstruction. However, there is overwhelming evidence for the massive overdiagnosis of disease in the elderly and underdiagnosis in young subjects when using a fixed ratio. In addition, a guideline for COPD in elderly subjects does not cater for respiratory disease in younger subjects. Hence, given the available research evidence ${ }^{43,62,64-74,80,85,150}$ and with support from the GOLD ${ }^{10}$ and ATS/ERS ${ }^{66}$ recommendations, the use of LLN values puts respiratory medicine in line with most other areas of investigation (e.g. blood parameters and dexa scanning). Most software packages provided by major spirometer manufacturers already provide LLN data. There is considerable evidence that high quality diagnostic spirometry is achievable and will improve clinical care. We recommend that health care commissioners set challenging, but achievable, targets in order to realise the recommendations documented in this guidance, and provide the necessary support and advice to help those involved deliver high quality spirometry in their communities.

This document will be updated in 2011.

\section{Acknowledgement}

The GPIAG was provided with an unrestricted educational grant by Vitalograph Ltd for the development of this paper. The manuscript was not seen by the sponsors before it was finalised by the authors, who were solely responsible for the writing 


\section{Conflict of interest declarations}

MLL has accepted sponsorship for attending conferences from, has accepted lecture fees from, or has been on advisory boards or provided consultancy for, the following companies; GlaxoSmithKline (GSK), AstraZeneca (AZ), Chiesi, Merck Sharpe and Dohme (MSD), Merck, Altana Pharma, Novartis, MEDA Pharmaceuticals, 3M Pharmaceuticals, Schering Plough, Boehringer Ingelheim (BI), Alk-Abello and Ranbaxy. He is the Editor-in-Chief of the PCRJ, but was not involved in the editorial review of, nor the decision to publish, this article.

PQ: no declared conflict of interest.

RB: no declared conflict of interest.

BC: no declared conflict of interest

$\mathrm{SH}$ has accepted sponsorship for attending conferences from, has accepted lecture fees from, or has been on advisory boards or provided consultancy for, the following companies; Altana Pharma, AZ, BI, GSK, MEDA Pharmaceuticals, MSD, Chiesi, Novartis and Schering Plough.

IS has recieved honouraria and support to attend international meetings from GSK, AZ, BI/Pfizer, Nycomed, TEVA and Chiesi. He is a trainer for Education for Health.

\section{References}

1. Darzi A. High Quality Care for All: NHS Next Stage Review final report. Available from: URL: http://www.dh.gov.uk/en/Publicationsandstatistics/ Publications/PublicationsPolicyAndGuidance/DH_085825. ISBN 978-0-10174322-8.Last accessed on 2009 Jan 21.

2. Department of Health. Delivering Care Closer to Home: Meeting the Challenge. Available from: URL: http://www.dh.gov.uk/en/ Publicationsandstatistics/Publications/PublicationsPolicyAndGuidance/DH_086 052. Last accessed on 2009 Jan 28.

3. Department of Health. Annual Report of the Chief Medical Officer 2004 on the state of public health. Available from: URL: http://www.dh.gov.uk/ en/Publicationsandstatistics/Publications/AnnualReports/DH_4115776.Last accessed on 2009 Jan 28.

4. Commission for Healthcare Audit and Inspection. Clearing the air: A national study of chronic obstructive pulmonary disease. Available from: URL: http://www.healthcarecommission.org.uk/.Last accessed on 2009 Jan 26.

5. Respiratory Alliance. Bridging the Gap: Commissioning and delivering high quality integrated respiratory healthcare. Available from: URL: http://www.gpiag.org/pubs/bridging-the-gap-final.pdf.Last accessed on 2003 Nov 30.

6. Miller MR, Hankinson J, Brusasco V, et al. Standardisation of spirometry. Eur Resp J 2005;26(2):319-38. http://dx.doi.org/10.1183/09031936.05.00034805

7. Levy ML, Fletcher M, Price DB, Hausen T, Halbert RJ, Yawn BP. International Primary Care Respiratory Group (IPCRG) Guidelines: Diagnosis of respiratory diseases in primary care. Prim Care Resp J 2006;15(1):20-34. http://dx.doi.org/10.1016/j.pcrj.2005.10.004.

8. National Institute for Clinical Excellence. Chronic obstructive pulmonary disease: management of adults with chronic obstructive pulmonary disease in primary and secondary care. Available from: URL: http://www.nice.org.uk/.

9. BTS/SIGN. British Thoracic Society, Scottish Intercollegiate Guidelines Network. British Guideline on the Management of Asthma. Available from: URL: http://www.brit-thoracic.org.uk.Last accessed on 2009 Jan 26.

10. National Institutes of Health NHLBI. Global Strategy for the Diagnosis, Management and Prevention of COPD, Global Initiative for Chronic Obstructive Lung Disease (GOLD) 2008. Available from: URL: http://www.goldcopd.com/.Last accessed on 2009 May 15.

11. The Royal College of Physicians of London/ BTS/BLF. Report 5 of The National Chronic Obstructive Pulmonary Disease Audit 2008:survey of COPD care within UK General Practices. 2008. 29-5-2009.

12. Bolton CE, lonescu AA, Edwards PH, Faulkner TA, Edwards SM, Shale DJ. Attaining a correct diagnosis of COPD in general practice. Respir Med 2005;99(4):493-500. http://dx.doi.org/10.1016/..rmed.2004.09.015

13. Lee $T A$, Bartle $B$, Weiss $K B$. Spirometry use in clinical practice following diagnosis of COPD. Chest 2006;129(6):1509-15. http://dx.doi.org/

\subsection{8/chest.129.6.1509}

14. Walters JA, Hansen E, Mudge P, Johns DP, Walters EH, Wood-Baker R. Barriers to the use of spirometry in general practice. Aust Fam Physician 2005;34(3): 201-03.

15. Dales RE, Vandemheen KL, Clinch J, Aaron SD. Spirometry in the primary care setting: Influence on clinical diagnosis and management of airflow obstruction. Chest 2005;128(4):2443-7.

16. Liistro G, Vanwelde C, Vincken W, Vandevoorde J, Verleden G, Buffels J. Technical and functional assessment of 10 office spirometers: A multicenter comparative study. Chest 2006;130(3):657-65. http://dx.doi.org/ 10.1378/chest.130.3.657

17. Department of Health. Investing in general practice: the new general medical services contract. Available from: URL: http://www.dh.gov.uk/en/ Publicationsandstatistics/Publications/PublicationsPolicyAndGuidance/DH_407 1966. Last accessed on 2009 Jan 26.

18. White P, Wong W, Fleming T, Gray B. Primary care spirometry: Test quality and the feasibility and usefulness of specialist reporting. $\mathrm{Br} / \mathrm{Gen}$ Pract 2007; 57(542):701-05.

19. Eaton T, Withy S, Garrett JE, Mercer J, Whitlock RML, Rea HH. Spirometry in primary care practice: The importance of quality assurance and the impact of spirometry workshops. Chest 1999;116(2):416-23. http://dx.doi.org/ 10.1378/chest.116.2.416

20. Hankinson JL. Office spirometry: Does poor quality render it impractical? Chest 1999;116(2):276-7. http://dx. doi.org/10.1378/chest.116.2.276

21. Schermer TR, Jacobs JE, Chavannes NH, et al. Validity of spirometric testing in a general practice population of patients with chronic obstructive pulmonary disease (COPD). Thorax 2003;58(10):861-6.

22. Enright/P. Provide GPs with spirometry, not spirometers. Thorax 2008;63(5): 387-8. http://dx.doi.org/10.1136/thx.2007.092916

23. Enright P. The use and abuse of office spirometry. Prim Care Resp J 2008;17(4): 238-42. http://dx.doi.org/10.3132/pcrj.2008.00065

24. Cooper BG. Limitations to spirometry being performed in 'the office'. Chron Respir Dis 2005;2(2):113-15. http://dx.doi.org/10.1191/1479972305cd072xx

25. Enright P. Spirometry should be measured in the offices of general practitioners. Chronic Resp Dis 2005;2(2):109-11. http://dx.doi.org/ 10.1191/1479972305cd071xx

26. Yawn BP, Enright PL, Lemanske J, et al. Spirometry can be done in family physicians' offices and alters clinical decisions in management of asthma and COPD. Chest 2007;132(4):1162-8. http://dx.doi.org/10.1378/chest.06-2722

27. British Lung Foundation. Survey of GPs and respiratory specialists about their experiences of diagnosing patients with COPD and Asthma. Available from: URL: http://www.lunguk.org/Resources/British_Lung_Foundation/Doctors_ Survey_report_Embargoed_until_00.pdf. Last accessed on 3 December 2008.

28. Upton J, Madoc-Sutton H, Sheikh A, Frank TL, Walker S, Fletcher M. National survey on the roles and training of primary care respiratory nurses in the UK in 2006: are we making progress? Prim Care Resp J 2007;16(5):284-90. http://dx.doi.org/10.3132/pcrj.2007.00068

29. Mulder $\mathrm{HH}$, van der Molen T, Postma DS. Measuring $\mathrm{FEV}_{1}$ in general practice. Eur Resp J 1996 (Suppl 9) 121s.

30. Woolhouse I, O'Hickey SP. Accuracy of spirometry measured in general practice compared to a hospital pulmonary function laboratory. Eur Resp J 1999 (Suppl 14[30]) 273s.

31. van Schayck CP, Loozen JMC, Wagena E, Akkermans RP, Wesseling GJ. Detecting patients at a high risk of developing chronic obstructive pulmonary disease in general practice: Cross sectional case finding study. BMJ 2002;324(7350):1370-3. http://dx.doi.org/10.1136/bmj.324.7350.1370

32. den Otter JJ, Knitel M, Akkermans RP, et al. Spirometry in general practice: the performance of practice assistants scored by lung function technicians. $\mathrm{Br} J$ Gen Pract 1997; 47(414):41-2.

33. Walters JA, Hansen EC, Johns DP, Blizzard EL, Walters EH, Wood-Baker R. A 
mixed methods study to compare models of spirometry delivery in primary care for patients at risk of COPD. Thorax 2008;63(5):408-14. http://dx.doi.org/10.1136/thx.2007.082859

34. Tuomisto L, Jarvinen V, Laitinen J, Erhola M, Kaila M, Brander P. Asthma Programme in Finland: the quality of primary care spirometry is good. Prim Care Resp J 2008;17(4):226-31. http://dx.doi.org/10.3132/pcrj.2008.00053

35. Poels PJ, Schermer TR, Schellekens DP, et al. Impact of a spirometry expert system on general practitioners' decision making. The European respiratory journal: official journal of the European Society for Clinical Respiratory Physiology 2008;31(1):84-92. http://dx.doi.org/10.1183/09031936.00012007

36. Hankinson JL, Gardner RM. Standard waveforms for spirometer testing. Am Rev Respir Dis 1982;126(2):362-4

37. Maree DM, Videler EA, Hallauer M, Pieper CH, Bolliger CT. Comparison of a new desktop spirometer (Diagnosa «) with a laboratory spirometer. Respiration 2001;68(4):400-04. http://dx.doi.org/10.1159/000050534

38. Swart F, Schuurmans MM, Heydenreich JC, Pieper CH, Bolliger CT. Comparison of a new desktop spirometer (Spirospec) with a laboratory spirometer in a respiratory out-patient clinic. Respir Care 2003;48(6):591-5

39. Chinn S, Jarvis D, Svanes C, Burney P. Sources of variation in forced expiratory volume in one second and forced vital capacity. Eur Resp J 2006;27(4):767-73. http://dx.doi.org/10.1183/09031936.06.00073105

40. Bednarek M, Maciejewski J, Wozniak M, Kuca P, Zielinski J. Prevalence, severity and underdiagnosis of COPD in the primary care setting. Thorax 2008;63(5): 402-07. http://dx.doi.org/10.1136/thx.2007.085456.

41. Zielinlski J, Bednarek M, Czajkowska-Malinowska M, et al. Early detection of COPD in a high-risk population using spirometric screening. Chest 2001;119(3):731-6. http://dx.doi.org/10.1378/chest.119.3.731

42. Cooper BG, Butterfield AK. Quality Control in Lung Function Testing. European Respiratory Society. Available from: URL: http://dev.ersnet.org/129-buyersguide.htm. (Accessed 12/7/2009)

43. Quanjer PH, Tammeling GJ, Cotes JE, Pedersen OF, Peslin R, Yernault JC. Lung volumes and forced ventilatory flows. Report Working Party Standardization of Lung Function Tests, European Community for Steel and Coal. Official Statement of the European Respiratory Society. Eur Respir J 1993;16:5-40.

44. Rutala DR, Rutala WA, Weber DJ, Thomann CA. Infection risks associated with spirometry. Infect Control Hosp Epidemiol 1991;12(2):89-92.

45. Burgos F, Torres A, lez J, Puig de la Bellacasa J, Rodriguez-Roisin R, Roca J. Bacterial colonization as a potential source of nosocomial respiratory infections in two types of spirometer. Eur Resp J 1996;9(12):2612-17.

46. Hiebert T, Miles J, Okeson GC. Contaminated aerosol recovery from pulmonary function testing equipment. Am J Respir Crit Care Med 1999;159(2):610-12.

47. Kendrick $A H$, Johns DP, Leeming JP. Infection control of lung function equipment: A practical approach. Respir Med 2003;97(11):1163-79. http://dx.doi.org/10.1016/S0954-6111(03)00223-3

48. Miller MR, Crapo R, Hankinson J, et al. General considerations for lung function testing. Eur Resp J 2005;26(1):153-61. http://dx.doi.org/10.1183/09031936.05.00034505

49. Tinkelman DG, Price DB, Nordyke RJ, Halbert RJ. COPD screening efforts in primary care: What is the yield? Prim Care Resp J 2007;16(1):41-8. http://dx.doi.org/10.3132/pcrj.2007.00009

50. Stratelis G, Jakobsson P, Molstad S, Zetterstrom O. Early detection of COPD in primary care: Screening by invitation of smokers aged 40 to 55 years. $\mathrm{Br} J$ Gen Pract 2004;54(500):201-06.

51. Price DB, Tinkelman DG, Halbert RJ, et al. Symptom-based questionnaire for identifying COPD in smokers. Respiration 2006;73(3):285-95. http://dx.doi.org/10.1159/000090142

52. Freeman D, Nordyke RJ, Isonaka S, et al. Questions for COPD diagnostic screening in a primary care setting. Respir Med 2005;99(10):1311-18. http://dx.doi.org/10.1016/j.rmed.2005.02.037

53. Pearson M. Chronic Obstructive Pulmonary Disease: National clinical guideline on management of chronic obstructive pulmonary disease in adults in primary and secondary care. Thorax 2004;59(Suppl 1):1-232.

54. GINA. The Global Strategy for Asthma Management and Prevention, Global Initiative for Asthma (GINA) Updated 2006. Available from: http://www.ginasthma.org. (Accessed 12/7/2009)

55. Crapo RO, Hankinson JL, Irvin C, et al. Standardization of spirometry: 1994 Update. Am J Respir Crit Care Med 1995;152(3):1107-36.

56. Spirometry For Health Care Providers. Global Initiative for Chronic Obstructive Lung Disease (GOLD). The Global Initiative for Chronic Obstructive Lung Disease (GOLD) . 2008. http://www.goldcopd.com/OtherResourcesltem.asp? $11=2 \& \mid 2=2$ \&intld=1836 (Accessed 12/7/2009)

57. Spirometry For Health Care Providers:Quick Guide- Global Initiative for Chronic Obstructive Lung Disease (GOLD). The Global Initiative for Chronic Obstructive Lung Disease (GOLD) . 2008. http://www.goldcopd.com/OtherResources Item.asp?|1=2\&|2=2\&intld=1837 (Accessed 12/7/2009)

58. Brener ND, McManus T, Galuska DA, Lowry R, Wechsler H. Reliability and validity of self-reported height and weight among high school students. Journal of Adolescent Health 2003;32(4):281-7. http://dx.doi.org/10.1016/S1054-139X(02)00708-5

59. Engstrom JL, Paterson SA, Doherty A, Trabulsi M, Speer KL. Accuracy of selfreported height and weight in women: An integrative review of the literature. J Midwifery and Women's Health 2003;48(5):338-45. http://dx.doi.org/10.1016/S1526-9523(03)00281-2

60. Rowland ML. Self-reported weight and height(1,2). Am J Clin Nutrition 1990;52(6):1125-33.

61. GPIAG. Spirometry Opinion. Available from: URL: http://www.gpiag.org/opinions/spirometry_revised_final_version_03.pdf.Last accessed on 2009 May 25.

62. Hankinson JL, Odencrantz JR, Fedan KB. Spirometric reference values from a sample of the general U.S. Population. Am J Respir Crit Care Med 1999;159(1): 179-87.

63. Stanojevic S, Wade A, Stocks J, et al. Reference ranges for spirometry across all ages: A new approach. Am J Respir Crit Care Med 2008;177(3):253-60. http://dx.doi.org/10.1164/rccm.200708-12480C

64. Falaschetti E, Laiho J, Primatesta P, Purdon S. Prediction equations for normal and low lung function from the health survey for England. Eur Resp J 2004;23(3):456-63. http://dx.doi.org/10.1183/09031936.04.00055204

65. Quanjer PH. Download the software. Available from: URL: www.spirxpert.com/GOLD.html.Last accessed on 2008 Dec 1.

66. Pellegrino $R$, Viegi $G$, Brusasco $V$, et al. Interpretative strategies for lung function tests. ATS/ERS Task Force Standardization of Lung Function Testing. Eur Resp J 2005;26(5):948-68. http://dx.doi.org/10.1183/ 09031936.05 .00035205

67. American Thoracic Society. Lung function testing: Selection of reference values and interpretative strategies. Am Rev Resp Dis 1991;144(5):1202-18.

68. Schermer TRJ, Quanjer PH. COPD screening in primary care: Who is sick? Prim Care Resp J 2007;16(1):49-53. http://dx.doi.org/10.3132/pcrj.2007.00012.

69. Swanney MP, Ruppel G, Enright PL, et al. Using the lower limit of normal for the FEV1/FVC ratio reduces the misclassification of airway obstruction. Thorax 2008;63(12):1046-51. http://dx.doi.org/10.1136/thx.2008.098483

70. Celli BR, Halbert RJ, Isonaka S, Schau B. Population impact of different definitions of airway obstruction. Eur Resp J 2003;22(2):268-73. http://dx.doi.org/10.1183/09031936.03.00075102

71. Hardie JA, Buist AS, Vollmer WM, Ellingsen I, Bakke PS, Morkve O. Risk of overdiagnosis of COPD in asymptomatic elderly never-smokers. Eur Resp J 2002;20(5): 1117-22. http://dx.doi.org/10.1183/09031936.02.00023202

72. Hnizdo E, Glindmeyer HW, Petsonk EL, Enright P, Buist AS. Case definitions for chronic obstructive pulmonary disease. COPD: J Chron Obstruct Pulm Dis 2006;3(2):95-100. http://dx.doi.org/10.1080/15412550600651552

73. Culver BH. Interpretation of spirometry: We can do better than the GOLD 
ML Levy et al.

standard. Respir Care 2006;51(7):719-21.

74. Hansen JE, Sun XG, Wasserman K. Spirometric criteria for airway obstruction: Use percentage of FEV 1/FVC ratio below the fifth percentile, not $<70 \%$. Chest 2007;131(2):349-55. http://dx.doi.org/10.1378/chest.06-1349

75. Roberts SD, Farber MO, Knox KS, et al. FEV1/FVC ratio of $70 \%$ misclassifies patients with obstruction at the extremes of age. Chest 2006;130(1):200-06. http://dx.doi.org/10.1378/chest.130.1.200

76. Shirtcliffe $P$, Weatherall $M$, Marsh $S$, et al. COPD prevalence in a random population survey: A matter of definition. Eur Resp J 2007;30(2):232-9 http://dx.doi.org/10.1183/09031936.00157906

77. Viegi G, Baldacci S, Vellutini M, et al. Prevalence rates of diagnosis of asthma in general population samples of northern and central italy. Monaldi Arch Chest Dis 1994;49(3):191-6.

78. Enright P, Quanjer P. Spirometry for COPD is both underutilized and overutilized. Chest 2007;132(2):368-70. http://dx.doi.org/10.1378/chest.070994

79. Akhtar R, Wilson A. A comparison of spirometry in general practice and a pulmonary function laboratory. Prim Care Resp J 2005;14(4):215-20 http://dx.doi.org/10.1016/j.pcrj.2004.12.005

80. Schermer TRJ, Smeele IJM, Thoonen BPA, et al. Current clinical guideline definitions of airflow obstruction and COPD overdiagnosis in primary care. Eur Respir J 2008;32(4):945-52.

81. Medbø A, Melbye $H$. Lung function testing in the elderly-Can we still use FEV1/FVC $<70 \%$ as a criterion of COPD? Respir Med 2007;101(6):1097-105

82. Enright PL. Are six seconds long enough? Prim Care Resp J 2006;15(5): 268-70. http://dx.doi.org/10.1016/j.pcrj.2006.07.004 .

83. Vandevoorde J, Verbanck S, Schuermans D, Kartounian J, Vincken W. Obstructive and restrictive spirometric patterns: Fixed cut-offs for FEV1/FEV6 and FEV6. Eur Resp J 2006;27(2):378-83. http://dx.doi.org/ 10.1183/09031936.06.00036005

84. Vandevoorde J, Verbanck S, Schuermans D, Kartounian J, Vincken W. FEV1/FEV 6 and FEV 6 as an alternative for FEV1/FVC and FVC in the spirometric detection of airway obstruction and restriction. Chest 2005;127(5):1560-4. http://dx.doi.org/10.1378/chest.127.5.1560

85. Vedal S, Crapo RO. False positive rates of multiple pulmonary function tests in healthy subjects. Bull Eur Physiopathol Respir 1983;19(3):263-6.

86. Glady CA, Aaron SD, Lunau M, Clinch J, Dales RE. A spirometry-based algorithm to direct lung function testing in the pulmonary function laboratory. Chest 2003;123(6):1939-46. http://dx.doi.org/10.1378/chest.123.6.1939

87. Celli BR, MacNee W, Agusti A, et al. Standards for the diagnosis and treatment of patients with COPD: A summary of the ATS/ERS position paper. Eur Resp $J$ 2004;23(6):932-46. http://dx.doi.org/10.1183/09031936.04.00014304

88. The COPD Guidelines Group of the Standards of Care Committee of the BTS BTS Guidelines for the management of chronic obstructive pulmonary disease. Thorax 1997;52(5):S1-S32.

89. Hansen EF, Rappeport Y, Vestbo J, Lange P. Prevalence of asthma among young adults in Copenhagen. Ugeskr Laeger 2001;163(44):6128-30.

90. Brusasco V, Pellegrino R, Rodarte JR. Vital capacities in acute and chronic airway obstruction: Dependence on flow and volume histories. Eur Resp $J$ 1997;10(6):1316-20

91. Becklake MR, Rodarte JR, Kalica AR. Scientific issues in the assessment of respiratory impairment. Am Rev Resp Dis 1988;137(6):1505-10.

92. Burrows B, Earle RH. Prediction of survival in patients with chronic airway obstruction. Am Rev Resp Dis 1969;99(6):865-71.

93. Traver GA, Cline MG, Burrows B. Predictors of mortality in chronic obstructive pulmonary disease. A 15-year follow-up study. Am Rev Resp Dis 1979;119(6) 895-902.

94. Beaty $\mathrm{TH}$, Cohen BH, Newill CA. Impaired pulmonary function as a risk factor for mortality. Am J Epidemiol 1982;116(1):102-13.

95. Lange P, Nyboe J, Appleyard M, Jensen G, Schnohr P. Spirometric findings and mortality in never-smokers. J Clin Epidemiol 1990;43(9):867-73. http://dx.doi.org/10.1016/0895-4356(90)90070-6

96. Ki MB, Gergen PJ, Kramer R, Cohen B. The effect of pulmonary impairment on all-cause mortality in a national cohort. Chest 1993;103(2):536-40. http://dx.doi.org/10.1378/chest.103.2.536

97. Hole DJ, Watt GCM, Davey-Smith G, Hart CL, Gillis CR, Hawthorne VM. Impaired lung function and mortality risk in men and women: Findings from the Renfrew and Paisley prospective population study. BMJ 1996;313(7059): 711-16.

98. Gorecka D, Gorzelak K, ski P, Tobiasz M, ski J. Effect of long term oxygen therapy on survival in patients with chronic obstructive pulmonary disease with moderate hypoxaemia. Thorax 1997;52(8):674-9.

99. Hansen EF, Phanareth K, Laursen LC, Kok-Jensen A, Dirksen A. Reversible and irreversible airflow obstruction as predictor of overall mortality in asthma and chronic obstructive pulmonary disease. Am J Respir Crit Care Med 1999;159(4 I):1267-71.

100. Knuiman MW, James AL, Divitini ML, Ryan G, Bartholomew HC, Musk AW. Lung function, respiratory symptoms, and mortality: Results from the Busselton Health Study. Annals of Epidemiol 1999;9(5):297-306. http://dx.doi.org/10.1016/S1047-2797(98)00066-0

101. Thomason MJ, Strachan DP. Which spirometric indices best predict subsequent death from chronic obstructive pulmonary disease? Thorax 2000;55(9):785-8. http://dx.doi.org/10.1136/thorax.55.9.785

102. Schunemann HJ, Dorn J, Grant BJB, Winkelstein W, Trevisan M. Pulmonary function is a long-term predictor of mortality in the general population: 29Year follow-up of the Buffalo Health Study. Chest 2000;118(3):656-64. http://dx.doi.org/10.1378/chest.118.3.656

103. Chinn S, Gislason T, Aspelund T, Gudnason V. Optimum expression of adult lung function based on all-cause mortality: Results from the Reykjavik study. Respir Med 2007;101(3):601-09. http://dx.doi.org/10.1016/ j.rmed.2006.06.009

104. Sorlie PD, Kannel WB, O'Connor G. Mortality associated with respiratory function and symptoms in advanced age: The Framingham Study. Am Rev Resp Dis 1989;140(2 I):379-84.

105.Teeter JG, Bleecker ER. Relationship between airway obstruction and respiratory symptoms in adult asthmatics. Chest 1998;113(2):272-7. http://dx.doi.org/10.1378/chest.113.2.272

106. Mahler DA, Weinberg DH, Wells CK, Feinstein AR. The measurement of dyspnea . Contents, interobserver agreement, and physiologic correlates of two new clinical indexes. Chest 1984;85(6):751-8. http://dx.doi.org/10.1378/chest.85.6.751

107. Wijnhoven HAH, Kriegsman DMW, Hesselink AE, Penninx BWJH, De Haan M. Determinants of different dimensions of disease severity in asthma and COPD: Pulmonary function and health-related quality of life. Chest 2001;119(4): 1034-42. http://dx.doi.org/10.1378/chest.119.4.1034

108. Brand PLP, Quanjer PH, Postma DS, et al. Interpretation of bronchodilator response in patients with obstructive airways disease. Thorax 1992;47(6):42936. http://dx.doi.org/10.1136/thx.47.6.429

109. Calverley PMA, Burge PS, Spencer S, Anderson JA, Jones PW, for the ISOLDE Study investigators. Bronchodilator reversibility testing in chronic obstructive pulmonary disease. Thorax 2003;58(8):659-64. http://dx.doi.org/ 10.1136/thorax.58.8.659

110.Dompeling $E$, van Schayck CP, Molema J, et al. A comparison of six different ways of expressing the bronchodilating response in asthma and COPD; reproducibility and dependence of prebronchodilator $\mathrm{FEV}_{1}$. Eur Resp J 1992;5(8):975-81.

111. Chhabra SK. Acute bronchodilator response has limited value in differentiating bronchial asthma from COPD. J Asthma 2005;42(5):367-72.

112. Silvestri IC, Pereira CADC, Rodrigues SCS. Comparison of spirometric changes in the response to bronchodilators of patients with asthma or chronic 
obstructive pulmonary disease. Jornal Brasileiro de Pneumologia 2008;34(9) 675-82.

113.Dales RE, Spitzer WO, Tousignant P, Schechter M, Suissa S. Clinica interpretation of airway response to a bronchodilator. Epidemiologic considerations. Am Rev Resp Dis 1988;138(2):317-20.

114. Anthonisen NR, Wright EC, Group IT. Bronchodilator response in chronic obstructive pulmonary disease. Am Rev Resp Dis 1986;133(5):814-19

115. Eliasson O, DeGraff J. The use of criteria for reversibility and obstruction to define patient groups for bronchodilator trials. Influence of clinical diagnosis, spirometric, and anthropometric variables. Am Rev Resp Dis 1985;132(4):85864.

116. Meslier N, Racineux JL, Six P, Lockhart A. Diagnostic value of reversibility of chronic airway obstruction to separate asthma from chronic bronchitis: A statistical approach. Eur Resp J 1989;2(6):497-505.

117. Anthonisen NR, Lindgren PG, Tashkin DP, Kanner RE, Scanlon PD, Connett JE. Bronchodilator response in the lung health study over 11 yrs. Eur Resp 2005;26(1):45-51. http://dx.doi.org/10.1183/09031936.05.00102604

118. Lehmann S, Bakke PS, Eide GE, Humerfelt S, Gulsvik A. Bronchodilator reversibility testing in an adult general population; The importance of smoking and anthropometrical variables on the response to a ?2-agonist. Pulm Pharmacol Ther 2006;19(4):272-80. http://dx.doi.org/10.1016/ j.pupt.2005.07.006

119. Lehmann S, Bakke PS, Eide GE, Gulsvik A. Bronchodilator response to adrenergic Beta-2-agonists: Relationship to symptoms in an adult community. Respir Med 2007;101(6):1183-90. http://dx.doi.org/10.1016/ j.rmed.2006.11.007

120. Douma WR, De Gooijer A, Rijcken B, et al. Lack of correlation between bronchoconstrictor response and bronchodilator response in a populationbased study. Eur Resp J 1997;10(12):2772-7.

121. Noseda A, Schmerber J, Prigogine T, Yernault JC. Perceived effect on shortness of breath of an acute inhalation of saline or terbutaline: Variability and sensitivity of a visual analogue scale in patients with asthma or COPD. Eur Resp J 1992;5(9):1043-53.

122. Kerstjens HA, Brand PL, Quanjer PH, van der Bruggen-Bogaarts BA, Koeter GH, Postma DS. Variability of bronchodilator response and effects of inhaled corticosteroid treatment in obstructive airways disease. Dutch CBSLD Study Group. Thorax 1993;7:722-9. http://dx.doi.org/10.1136/thx.48.7.722

123. Alsaeedi A, Sin DD, McAlister FA. The effects of inhaled corticosteroids in chronic obstructive pulmonary disease: A systematic review of randomized placebo-controlled trials. Am f Med 2002;113(1):59-65. http://dx.doi.org/10.1016/S0002-9343(02)01143-9

124. Hay JG, Stone P, Carter J, et al. Bronchodilator reversibility, exercise performance and breathlessness in stable chronic obstructive pulmonary disease. Eur Resp J 1992;5(6):659-64.

125. Belman MJ, Botnick WC, Shin JW. Inhaled bronchodilators reduce dynamic hyperinflation during exercise in patients with chronic obstructive pulmonary disease. Am J Respir Crit Care Med 1996;153(3):967-75.

126. O'Donnell DE, Lam M, Webb KA. Spirometric correlates of improvement in exercise performance after anticholinergic therapy in chronic obstructive pulmonary disease. Am J Respir Crit Care Med 1999;160(2):542-9.

127. Tantucci C, Duguet A, Similowski T, Zelter M, Derenne JP, Milic-Emili J. Effect of salbutamol on dynamic hyperinflation in chronic obstructive pulmonary disease patients. Eur Resp J 1998;12(4):799-804.

128. Ramirez-Venegas A, Ward J, Lentine T, Mahler DA. Salmeterol reduces dyspnea and improves lung function in patients with COPD. Chest 1997;112(2):336-40. http://dx.doi.org/10.1378/chest.112.2.336

129. O'Donnell DE, Lam M, Webb KA. Measurement of symptoms, lung hyperinflation, and endurance during exercise in chronic obstructive pulmonary disease. Am J Respir Crit Care Med 1998;158(5 part I):1557-65.

130. O'Donnell DE, Forkert L, Webb KA. Evaluation of bronchodilator responses in patients with "irreversible" emphysema. Eur Resp J 2001;18(6):914-20. http://dx.doi.org/10.1183/09031936.01.00216501

131. Pellegrino R, Brusasco V. Lung hyperinflation and flow limitation in chronic airway obstruction. Eur Resp J 1997;10(3):543-9.

132. Pellegrino R, Rodarte JR, Brusasco V. Assessing the Reversibility of Airway Obstruction. Chest 1998;114(6):1607-12. http://dx.doi.org/10.1378/ chest.114.6.1607

133. Appleton SL, Adams RJ, Wilson DH, Taylor AW, Ruffin RE. Spirometric criteria for asthma: Adding further evidence to the debate. I All \& Clin Immun 2005;116(5):976-82.

134. Bussamra MH, Cukier A, Stelmach R, Rodrigues JC. Evaluation of the magnitude of the bronchodilator response in children and adolescents with asthma. Chest 2005;127(2):530-5. http://dx.doi.org/10.1378/chest.127.2.530

135.Dundas I, Chan EY, Bridge PD, McKenzie SA. Diagnostic accuracy of bronchodilator responsiveness in wheezy children. Thorax 2005;60(1):13-16. http://dx.doi.org/10.1136/thx.2004.029934

136. Pardos M, Fuertes F, de la Puerta I, Gonzalez Perez-Yarza. Cut-off point for a positive bronchodilation test. Anales Espanoles de Pediatria 2002;57(1):5-11.

137. Ouksel H, Meslier N, Badatcheff-Coat A, Racineux JL. Influence of predicted FEV1 on bronchodilator response in asthmatic patients. Respiration 2003;70(1): 54-9. http://dx.doi.org/10.1159/000068419

138. Burrows B, Lebowitz MD, Camilli AE, Knudson RJ. Longitudinal changes in forced expiratory volume in one second in adults. Methodologic considerations and findings in healthy nonsmokers. Am Rev Resp Dis 1986;133(6):974-80.

139. Lebowitz MD, Quackenboss J, Camilli AE, Bronnimann D, Holberg CJ, Boyer B. The epidemiological importance of intraindividual changes in objective pulmonary responses. Eur J Epidemiol 1987;3(4):390-8. http://dx.doi.org/10.1007/BF00145651

140. Borsboom GJJM, van Pelt W, Van Houwelingen HC, Van Vianen BG, Schouten JP, Quanjer PH. Diurnal variation in lung function in subgroups from two Dutch populations: Consequences for longitudinal analysis. Am J Respir Crit Care Med 1999;159(4 I):1163-71.

141. Berry G. Longitudinal observations. Their usefulness and limitations with special reference to the forced expiratory volume. Bull Physio-Path Resp 1974;10(5): 643-56.

142. Pennock BE, Rogers RM, McCaffree DR. Changes in measured spirometric indices. What is significant? Chest 1981;80(1):97-9. http://dx.doi.org/10.1378/chest.80.1.97

143. Rozas CJ, Goldman AL. Daily spirometric variability. Normal subjects and subjects with chronic bronchitis with and without airflow obstruction. Arch Int Med 1982;142(7):1287-91.

144. Enright PL, Connett JE, Kanner RE, Johnson LR, Lee WW. Spirometry in the lung health study: II. Determinants of short-term intraindividual variability. Am J Respir Crit Care Med 1995;151(2 I):406-11.

145. Herpel LB, Kanner RE, Lee SM, et al. Variability of spirometry in chronic obstructive pulmonary disease: Results from two clinical trials. Am J Respir Crit Care Med 2006;173(10):1106-13. http://dx.doi.org/10.1164/rccm.200506$9750 \mathrm{C}$

146. Harrison AJ, Urbanski H, Moore E. Quality Control of respiratory measurements in global trials. Eur Resp J 2006;28:Abstract No.984 presented ERS

147. Harrison AJ, Priestly R, Khan M. Improving spirometry in pharmaceutical Clinical Trials. Eur Resp J 2008;32:Abstract No.3216 presented ERS.

148. Bellia V, Pistelli R, Catalano F, et al. Quality control of spirometry in the elderly. The SA.R.A. study. (SAlute Respiration nell'Anziano : Respiratory Health in the Elderly). Am J Respir Crit Care Med 2000;161(4 Pt 1):1094-100.

149.Derom E, van Weel C, Liistro G, et al. Primary care spirometry. Eur Resp J 2008;31(1):197-203. http://dx.doi.org/10.1183/09031936.00066607

150. Miller MR, Pincock AC. Predicted values: How should we use them? Thorax 1988;43:265-7. http://dx.doi.org/10.1136/thx.43.4.265 
ML Levy et al.

\section{Appendix 1 Template of spirometry check list.}

Please complete for each patient and attach the spirometry print out to the form for reporting.

Date

Patient Name:

Time of testing

DoB.

1. Smoker? $\ldots \ldots \ldots \ldots \ldots \ldots \ldots \ldots \ldots \ldots \ldots \ldots \ldots \ldots \ldots$
If 'Yes', time of last cigarette $\ldots \ldots \ldots \ldots$
2. Eaten in the last two hours? ........................

3. List all current medication (particularly inhalers) and when they were last taken. Name: Last taken (date \& time):

4. Check contraindications.

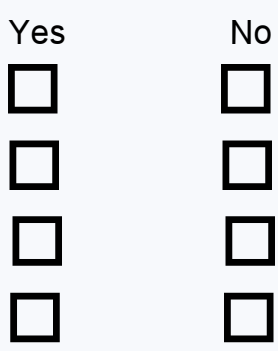

Current chest infection?

Heart attack or surgery in previous 6 wks?

Coughing blood or history of pneumothorax?

Previous stroke or uncontrolled high blood pressure?
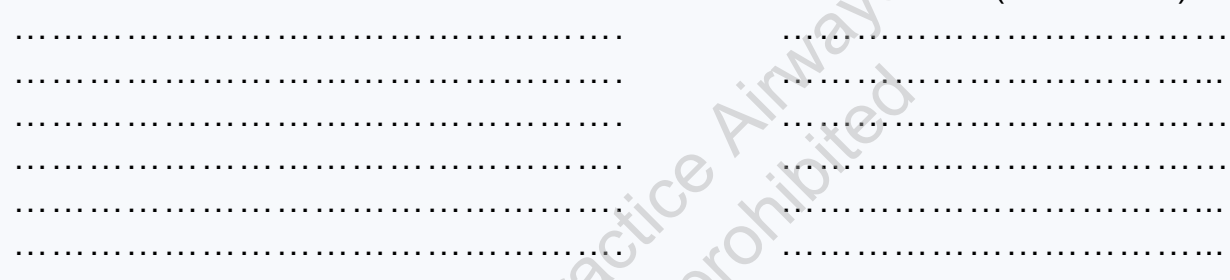

If patient answers yes to any of the above please ask the doctor requesting the test before proceeding)

Measured height (without shoes)

Weight.

Position for testing (sitting or standing)....

Please record how well the patient was able to co-operate and whether you experienced any difficulty with the recording.

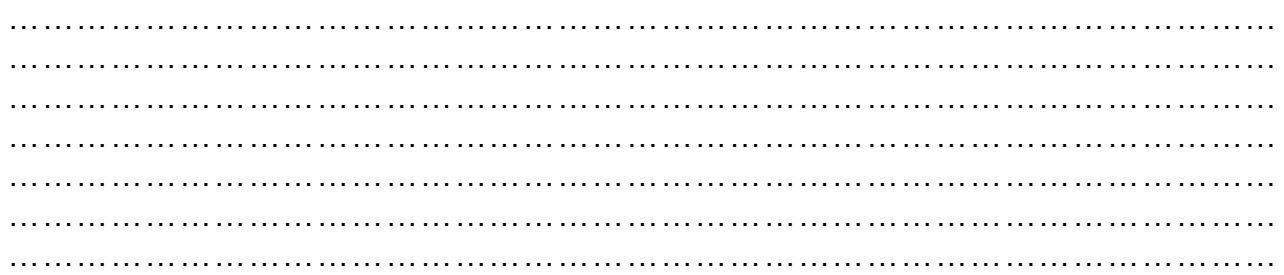

Your name (in print) 
Diagnostic Spirometry in Primary Care

\section{Appendix 2 Example of spirometry printout.}

Name : John Doe

Age:

44

Height (cm): 184

Weight (kg): 86

BMI : $\quad 25.4$

\begin{tabular}{lcrrrrrr} 
& & \multicolumn{6}{c}{ Pre Bronchodilator } \\
\cline { 3 - 8 } & & Actual & Pred & LLN & SDS & \%pred & Obstr \\
FEV1/FVC & (\%) & 51.7 & 78.3 & 69.3 & -3.85 & & $<$ \\
FEV 1 & (L) & 2.59 & 4.46 & 3.54 & -3.33 & 58.1 & $\downarrow \downarrow$ \\
FVC & (L) & 5.01 & 5.67 & 4.58 & -0.99 & 88.4 & \\
Acceptability/Repeatability & $+/+$ & & &
\end{tabular}

Patient ID: 03091964

Date: Jan. 14, 2009

Time: 11:44

Ethnicity: white
Gender : male

Ref.values: Stanojevic 2008

Physician:

Technician: NN

< below LLN; Obstruction: - No; $\downarrow$ mild; $\downarrow \downarrow$ moderate; $\downarrow \downarrow \downarrow$ severe; $\downarrow \downarrow \downarrow \downarrow$ very severe

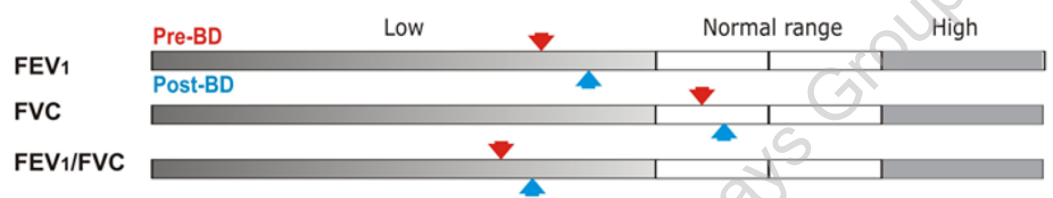

Volume (L)

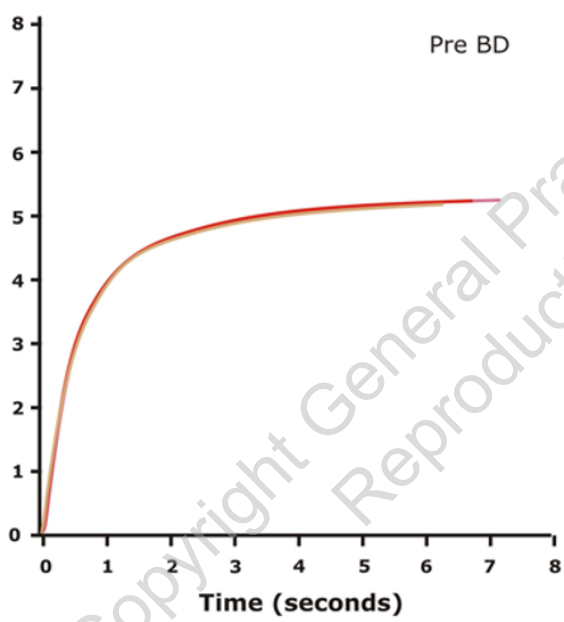

Volume (L)

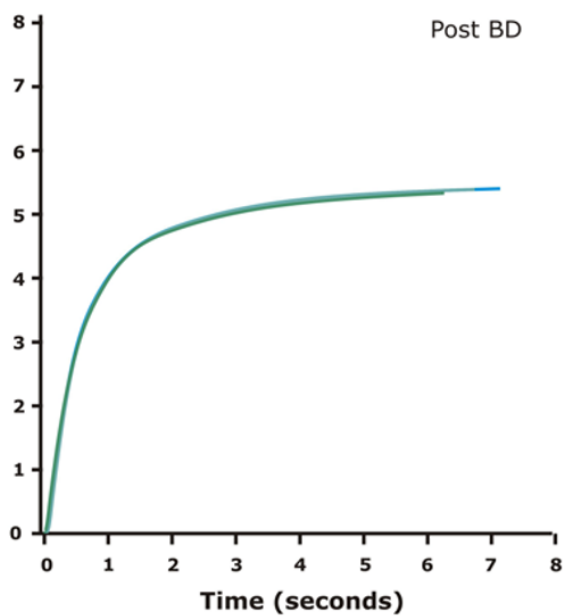

Post Bronchodilator

\begin{tabular}{|c|c|c|c|c|}
\hline Actual & SDS & \%pred & $\%$ Change & Obstr \\
\hline 55.8 & -3.42 & & & $<$ \\
\hline 2.97 & -2.65 & 66.6 & 14.7 & $\downarrow \downarrow$ \\
\hline 5.32 & -0.53 & $\begin{array}{r}93.8 \\
+/+\end{array}$ & 6.2 & \\
\hline
\end{tabular}

